University of Michigan Law School

University of Michigan Law School Scholarship Repository

Articles

Faculty Scholarship

8-1978

\title{
Glosses on Dworkin: Rights, Principles, and Policies
}

Donald H. Regan

University of Michigan Law School, donregan@umich.edu

Follow this and additional works at: https://repository.law.umich.edu/articles

Part of the Jurisprudence Commons, Law and Philosophy Commons, Litigation Commons, and the Torts Commons

\section{Recommended Citation}

Regan, Donald H. "Glosses on Dworkin: Rights, Principles, and Policies." Mich. L. Rev. 76 (1978): 1213-64.

This Article is brought to you for free and open access by the Faculty Scholarship at University of Michigan Law School Scholarship Repository. It has been accepted for inclusion in Articles by an authorized administrator of University of Michigan Law School Scholarship Repository. For more information, please contact

mlaw.repository@umich.edu. 


\title{
GLOSSES ON DWORKIN: RIGHTS, PRINCIPLES, AND POLICIES
}

\author{
Donald H. Regan* $\dagger$
}

A great many people have attempted to explain what is wrong with the views of Ronald Dworkin. So many, indeed, that one who read only the critics might wonder why views so widely rejected have received so much attention. One reason is that, whatever may be wrong in Dworkin's theories, there is a good deal that is right in them. But what is right is not always clear. Important passages in Dworkin can be distressingly obscure, or tantalizingly incomplete.

This essay is a set of loosely connected observations on themes from Dworkin. While I shall add some criticisms of my own to the list of charges against Dworkin, my primary object is to defend and to amplify, clarifying here, filling in gaps there. I shall concentrate on what Dworkin has to say about the nature of rights, principles, and policies. I shall not address directly issues about the relation of law to morality. The omission just indicated makes it clear that I am not engaged in a comprehensive review of Dworkin's position.

It is in the nature of this essay to have no unifying theme. Various parts of the essay do, however, converge in supporting the following observation: Individuals, and relations between individuals, are squarely at the center of Dworkin's picture of the common law. For the most part (not invariably) Dworkin seems to operate with a rather old-fashioned idea of the common law as a system based on fundamental moral principles, understandable by all, regulating intercourse between individuals and referring only incidentally to general social consequences. The centrality of the individual is revealed both in judgments about what are appropriate occasions for judicial intervention and in judgments about what reasons for decision it is appropriate for judges to consider. The suggestion that Dworkin tends to focus on individuals should not surprise anyone who has read his essays. What may be surprising is the number of Dworkin's claims that turn out on analysis to reflect this tendency.

* Professor of Law, University of Michigan. A.B. 1963, Harvard University; LL.B. 1966, University of Virginia; B. Phil. 1968, Oxford University.-Ed.

$\dagger$ I should like to thank my colleagues Rick Lempert, Sallyanne Payton, Phil Soper, and Joe Vining for many helpful comments on a previous draft of this essay.

1213 


\section{RIGHTS}

In a recent review of Taking Rights Seriously, Joseph Raz devotes considerable attention to Dworkin's view of the nature of rights. ${ }^{1}$ After arguing that Dworkin's claims are obscure and apparently contradictory, Raz seems to despair of finding in Dworkin any interesting view at all. My own opinion is that Dworkin's writings contain two distinct interesting views about the nature of rights. Dworkin does not treat these views as distinct, but I shall show that certain of Dworkin's arguments about rights require that the two views be kept separate. ${ }^{2}$

\section{A. Rights as Trumps}

On one view, a right is a sort of political trump. The simplest way to elucidate the idea of "rights as trumps" is to sketch a theory about political goals in which such rights figure. The theory I shall sketch is Dworkinian in its basic conception and illuminates various features of Dworkin's views. It may not represent perfectly Dworkin's current theory of political goals. Dworkin's essays, written over a number of years and republished recently without any attempt at harmonization, do not add up to a definitive statement of what Dworkin believes.

According to the theory I shall consider, and to a first approximation, the basic purpose of civil government is to provide for the satisfaction of the preferences of individual citizens. ${ }^{3}$ The basic purpose is not to produce great philosophers, nor to advance science or

1. Raz, Professor Dworkin's Theory of Rights, 26 Political Stud. 123 (1978).

2. I wrote this essay before I had access to Dworkin's own response to Raz, which appears in the expanded R. DwORKIN, TAKING RIGHTS SERIOUSLY 364 (paperback ed. 1978) [hereinafter cited as RIGHTS (p)]. Had I had Dworkin's response in hand, I might have written Part I.A somewhat differently, but $I$ think no changes are required, and I have made none in the text. I have added some footnotes.

It seems to me that Dworkin's response to Raz confirms many of my suggestions about Dworkin's meaning and disconfirms none of them. There is this principal difference: Dworkin continues to assume an unanalyzed notion of rights as trumps and emphasizes that rights as trumps may exist in political systems which recognize various general background justifications for political decisions. I provide a more detailed sketch than Dworkin does of how rights as trumps might be built into a system which takes as its background justification a utilitarian notion of the general welfare. Most of Dworkin's writings, focussing as they do on American and British political theory, are about such systems.

My treatment in Part I.A supplements Dworkin's response to Raz; it suggests, in the digressive note 18, some criticisms of Dworkin's position which differ from Raz's; and it provides the foundation for the argument in Part I.B that Dworkin needs some notion of rights in addition to the notion of rights as trumps if he is to maintain his claim that all private litigation involves rights.

3. I shall simply ignore, here and elsewhere, the genuine and significant issue of how a government ought to behave toward noncitizens, whether within or without its territorial jurisdiction. 
the arts, nor to produce the highest possible level of economic welfare subject to a constraint of precise material equality, nor to approach any other conception of the ideal state. The basic purpose is to let people have and do what they want as fully as possible. Inevitable conflicts between individual preferences are to be resolved along traditional utilitarian lines. Government should seek to maximize the aggregate satisfaction of preferences, taking intensity of preference into account.

So far we have referred to nothing resembling rights. Rights come into this sketch as a refinement of the basic purpose we have postulated for government. Rights are preferences which are given special weight. (More accurately, perhaps, rights are special protections accorded certain preferences in the form of extra weighting.) Thus, to say that someone has a right of political expression is to say that his preference for indulging in political expression is given more weight than ordinary run-of-the-mill preferences (that is, preferences not protected by rights) of the same intensity. The purpose of government, once rights are taken into account, is to maximize the aggregate satisfaction of preferences where the method of aggregation respects both the varying intensity of preferences and the special weights accorded to any preferences because they are protected by rights.

This sketch of the nature of rights ${ }^{4}$ makes it clear in what sense rights can override considerations of the general welfare, and why it is appropriate for Dworkin to refer to rights as "anti-utilitarian". If I have no right of political expression, then it is a sufficient justification for forbidding me to speak that the aggregate satisfaction of everyone's preferences (including mine, of course, and taking account of the intensity of all relevant preferences) will be greater if I am silent. But if $I$ have a right to speak, then the same balance of other preferences which was sufficient to outweigh my bare desire to speak may not outweigh my desire when it is given the extra weight it acquires by virtue of the right. Thus my having a right may tip the balance against a governmental action which would be justified by reference to the general welfare if the right did not exist.

4. It will occur to some readers at this point that the sketch in the text makes no use of Dworkin's concept of "external preferences". My reasons for essentially ignoring that concept are explained in note 18 infra.

5. See, e.g., R. DWORKIN, TAKING RIghts SERIOUSLY 269 (hardback ed. 1977) (hereinafter cited as RIGHTS (h)]. The paperback, supra note 2, and the hardback editions are identical in content and pagination, except that the paperback has an appendix which is a revised and expanded version of Dworkin, Seven Critics, 11 GA. L. REv. 1201 (1977) [hereinafter cited as Seven Critics]. 
The preceding paragraph establishes that it is not a sufficient argument for denying a right that the aggregate satisfaction of preferences, measured without reference to the special weight the right confers on certain preferences, would be marginally increased by doing so. A corollary of this proposition is the following: If it is a sufficient justification for the government's defeating some preference that the general welfare is marginally served thereby, then the preference in question is not protected by a right. This is the basis for what I shall call the "Lexington Avenue argument". Dworkin writes at one point: "I have no political right to drive up Lexington Avenue. If the government chooses to make Lexington Avenue one-way down town, it is a sufficient justification that this would be in the general interest . ..." The context makes it clear that the second sentence just quoted is intended as a rather elliptical argument for the claim in the first sentence that Dworkin has no right to drive up Lexington Avenue. Our sketch of the nature of rights reveals why, in Dworkin's view, the argument is valid.

I have paused over the Lexington Avenue argument for two reasons. First, I shall use the argument myself against a claim of Dworkin's in the next section of this essay. Second, the argument seems to have occasioned some confusion. Raz, for example, thinks the Lexington Avenue argument must rest on the claim that "rights cannot be defeated by considerations of the general interest or by any other considerations."7 I do not know why Raz adds the phrase "or by any other considerations," since the Lexington Avenue argument plainly speaks to nothing but the relation between claims of right and the general interest. The important point, however, is that the Lexington Avenue argument does not depend even on a claim that "rights cannot be defeated by considerations of the general interest." What the argument depends on is the claim that not just any marginal increase in the general welfare which would flow from denying a right can justify that denial. So long as there is no right to drive up Lexington Avenue, then the possibility of achieving even the slightest increase in the general welfare justifies making Lexington Avenue one-way downtown. If there is a right to drive up Lexington Avenue, however, it takes more than this marginal advantage to the general welfare to justify making the Avenue one-way the other way. In sum, the Lexington Avenue argument does not depend on the claim that rights can never be defeated by considerations of the general interest.

6. Rights (h), supra note 5, at 269.

7. Raz, supra note 1 , at 126 . 
It depends only on the claim that rights cannot be defeated by the same considerations of the general interest that would justify defeating the relevant preferences if they were not protected by rights. ${ }^{8}$

This is an appropriate point at which to call attention to another feature of our sketch. It allows for rights of widely differing importance. To say that there is a right to something is only to say that a preference for that something gets some extra weight. It is not to say anything about how much extra weight. A right which guarantees the preference it protects only a little extra weight is a weak right, but a right nonetheless. The interesting rights, to be sure, are the strong ones, those that confer a great deal of extra weight on the preferences they protect. But the logic of rights does not require that rights be strong, or interesting. Far from suggesting that rights cannot be defeated by considerations of the general interest, our sketch leaves open the possibility that some rights can be denied in order to produce relatively small gains in the aggregate satisfaction of preferences. ${ }^{9}$

The sketch we are considering is a sketch of the logic of rights, no more. As noted in the previous paragraph, it does not tell us how important any particular right is. More generally, it tells us nothing (by itself) about what rights we have. Despite this, the sketch generates some significant arguments. Dworkin employs the central idea of the sketch when he argues in the essay "Taking Rights Seriously"

8. There is an ambiguity in natural language which contributes to confusion about the Lexington Avenue argument. Dworkin says that there is no right to drive up Lexington Avenue because it is a sufficient justification for making the Avenue one-way downtown that that would be in the general interest. If I am correct, what Dworkin means is that there is no right because the supposed right can be denied in order to secure any net advantage to the general interest, however small. That is a perfectly natural construction of what Dworkin says. But it is also possible to construe Dworkin's words as Raz does, that is, as saying that there is no right because there is some advantage (perhaps very large) to the general interest which would justify making the Avenue one-way downtown. I think my interpretation of Dworkin makes better sense than Raz's interpretation. But I recognize the ambiguity. Indeed, I am specially sensitive to it because I shall from time to time appeal to the Lexington Avenue argument in what follows. The reader should bear in mind that when I make assertions like Dworkin's in the Lexington Avenue argument, I mean those assertions to be construed as I construe Dworkin's.

9. Dworkin sometimes speaks as if rights must always be important or weighty. There are two possible explanations for this which would not undermine what I suggest in the text about the logic of rights. First, for purposes of thinking about practical problems, the only rights which make a difference are rights which confer considerable extra weight. The discriminations we can make in practice about the balance of preferences are not sufficiently fine to notice any rights but these. Second, Dworkin plainly thinks that the rights he is most interested in, the right to free speech, the right to follow one's inclinations in private sexual behavior, and so on, are among those rights which confer on the preferences they protect substantial extra weight. To establish this requires argument about more than the logic of rights, and I do not think Dworkin establishes it. But he expects his readers to share his intuitions, and probably most of them do. 
that a right maintains its power to override the general welfare over the whole range of its relevance, or in other words that a right does not just naturally lose its power to override (some) arguments based on the general welfare as the range of cases in which the right is recognized moves further and further beyond the unambiguous "core" cases. ${ }^{10}$ Dworkin employs the same idea in his argument that the government cannot justify enforcing a law it had no right to pass in the first place on the ground that non-enforcement will lead to a marginal decrement in respect for law. " The same idea is at the center of the argument in "What Rights Do We Have?" that there is no general right to liberty. ${ }^{12}$ I do not suggest that these arguments are unproblematic. But they are significant, and they flow directly from the logic of rights embodied in the sketch.

Our sketch also accounts very neatly for Dworkin's apparent view that an individual does not have a right to his own welfare. ${ }^{13}$ If Jones has a right to his own welfare, then all of Jones' preferences are entitled to extra weight in the aggregating process. But if Jones has this right, then so does everyone else. (This is an assumption. I assume that if the right to one's own welfare exists, then it is a universal right.) If everyone has the right, then all of everyone's preferences are entitled to extra weight. But if all of everyone's preferences are entitled to extra weight, then in effect no preference is given extra weight, at least on the basis of this particular right. In sum, the very idea of a (universal) right to one's own welfare is incoherent.

Note that the argument just given does not preclude a right to some minimum level of welfare. We could give extra weight to all preferences which must be satisfied if we are to bring everyone up to some specified minimum level of satisfaction. Provided the level specified can be achieved for everyone without exhausting the society's resources, recognition of this right will not result in giving extra weight to all preferences, and so will not lead to incoherence. I suspect that most proponents of a "right to welfare" have in mind a right to some minimum level of welfare. It is a virtue of the sketch that it explains how there can be a right to minimum welfare at the same time that it explains why the notion of a right to welfare in general, not limited at any level of satisfaction, is problematic. ${ }^{14}$

10. Rights (h), supra note 5 , at 197-204.

11. Id. at 193.

12. Id. at 266-72.

13. Cf. RIGHTS (h), supra note 5 , at 266-72 (arguing against a general right to liberty).

14. Compare Dworkin's new discussion of rights to welfare and of rights to minimum welfare. RiGHTS (p), supra note 2, at 366-67.

Dworkin's discussion suggests a qualification to the argument in the text. The idea of a 
Let me turn now to a few criticisms that are likely to be made of our sketch. It may appear that the sketch, in addition to not telling us what rights we have, falls hopelessly short of accommodating all the rights we think we have, or all the rights Dworkin thinks we have. How, for example, do we fit the right to equal concern and respect, or the right not to be discriminated against on the basis of race, into this picture of rights as specially weighted preferences without gross distortion? There are difficulties here, but they may be less than they appear at first.

As to the right to equal concern and respect, that is not just $a$ right in Dworkin's scheme. It is the right, the foundation of everything else. This right is not one to be analyzed as a specially weighted preference. Rather, this right is embodied in the very structure of the scheme, in the idea that the basic purpose of government is to promote the satisfaction of preferences, some of them, perhaps, given special weight. Equal concern is reflected in the fact that everyone's preferences are counted equally, and some degree of respect is reflected in the fact that counting only preferences excludes governmental enforcement of ideals which are not widely shared by the citizenry. ${ }^{15} \mathrm{~A}$ further degree of respect can be guaranteed, and in a fully spelled-out theory presumably would be guaranteed, by the assignment of special weights to certain preferences (such as that for free speech or for particular forms of sexual expression) which we think cannot be denied without invading the personality of the individual. ${ }^{16}$

As to the right not to be discriminated against on the basis of race, matters are more complicated. We must consider just what we mean by this right. If we mean a right not to have one's preferences ignored or discounted because of one's race, then of course the right to non-discrimination so understood is embodied in the sketch as one way of specifying the general right to equal concern and respect.

universal right to general welfare is incoherent only in the context of a theory in which the basic goal of government, which the existence of rights modifies, is the satisfaction of individual preferences. In the context of a different sort of theory, such as the theory that government exists to promote religious salvation, the idea of a universal right to general welfare would not be incoherent, but it would tend to supplant the other basic purpose of government. There is more to be said about this than Dworkin says, or than I am prepared to say here. As I pointed out in note 2 supra, this essay assumes, as Dworkin usually seems to assume, that the "unrefined" basic purpose of government is to promote the satisfaction of individual preferences.

15. Rights (h), supra note 5, at 274.

16. Compare Righrs (p), supra note 2, at 368 (quoting Rights (h), supra note 5, at xv): The right to be treated as an equal is " so fundamental that it is not captured by the general characterization of rights as trumps . . . because it is the source both of the general authority of collective goals and of the special limitations on their authority that justify more particular rights." " 
If, on the other hand, we mean a right not to have race used as a basis for any legal classification, then I doubt that there is such a right at the most fundamental theoretical level. We are rightly suspicious of any use of racial classifications, both because we think race is presumptively irrelevant to most problems the law deals with, and because racial criteria have been appallingly misused. But I do not see how it can be said that race could never be an appropriate basis for classification in a scheme that maximized satisfaction of everyone's preferences, correctly weighted and aggregated. (Lest it be objected that the last sentence simply demonstrates the inadequacy of the whole maximizing-of-satisfaction approach, I will say that I do not see how race could be absolutely forbidden as a basis of classification on any plausible political theory.) The sketch I have offered is intended to capture the logic of theoretically fundamental rights, and if the "right" not to have race used as a basis for classification is not such a right, it is no objection to the sketch that it cannot accommodate it. Note that accepting the sketch as a sketch of the logic of fundamental rights does not exclude the possibility of stringent constitutional rules, such as a flat ban on the use of race as a classification, if such rules are desirable in practice as protection against abuse of political power. ${ }^{17}$

Another possible criticism of our sketch is that it allows any right to be overridden by a sufficiently strong argument based just on the general welfare. No matter how much extra weight is given to any particular preference (provided it is not an infinite weight, which would involve us in other difficulties), it is logically possible that the balance of other relevant preferences should be enough to outweigh that one preference. This may be a defect of the sketch. It will appear to some readers that while any right must give way in the face of some imaginable disasters, yet there are some rights that cannot be violated just to produce an increase in general welfare (assuming we are already above some reasonable minimum) no matter how great that increase might be. Dworkin himself might take this view. We could make selected rights impervious to supposed justifications for denial based on increases (of whatever magnitude) in the general welfare by according lexicographical priority to certain preferences

17. Compare Dworkin's recent suggestion that the right of non-discrimination is not theoretically fundamental, RiGHTS (p), supra note 2 , at 365 :

The claim that members of some minority have particular rights in such a society (like the right to an integrated education, possibly) will appeal to features [of the society] not necessarily present elsewhere. But many rights are universal, because arguments are available in favour of these rights against any collective justification in any circumstances reasonably likely to be found in political society. It is these that might plausibly be called human rights. 
in certain circumstances. I shall not pursue this complication, which would have little or no effect on the rest of this essay.

There may be readers who wonder whether the sketch I have offered is defensible as an interpretation of Dworkin. The sketch does not employ Dworkin's concept of "external preferences". For reasons discussed in a footnote, I tend to regard the essays on external preferences as interesting digressions from the main current of Dworkin's theorizing. ${ }^{18}$ Aside from that, the sketch captures neatly the idea of rights as trumps, and it allows us to account crisply for some claims Dworkin leaves incompletely justified.

There is another respect in which the sketch is thoroughly

18. External preferences, as defined by Dworkin, are preferences about the degree to which preferences of other persons (that is, persons other than the possessor of the "external" preference in question) should be satisfied. RIGHTS (h), supra note 5, at 234-35. Dworkin suggests that certain rights are best understood as protection against legislation which is likely to be passed (if it is passed at all) in response to external preferences. See generally id. at 235-39, and for a more pointed statement, id. at 277-78.

My principal objection to the external preferences analysis is this: Dworkin suggests that we want to prohibit "decisions that seem, antecedently, likely to [be] reached by virtue of the external components of the preferences democracy reveals." Id. at 277. He then specifically defends minimum-wage legislation on the ground that it is not antecedently likely to give effect to external preferences. Id. at 278. But I should think that in a populous and heterogeneous democracy like our own almost every law is passed in response to external preferences and that these preferences are crucial as often as not. Surely most minimum-wage legislation, like most other legislation protecting specific groups, depends for its passage on the existence of widespread external preferences. Persons not directly affected seek such legislation to promote what they perceive as a more just distribution of income or of the benefits of social life generally. Indeed, it seems to me that Dworkin concedes this in the newly added appendix to Taking Rights Seriously. He says: "[People] will vote their external preferences; they will vote for legislators, for example, who share their own theories of political justice. How else should they decide for whom to vote?" RIGHTS (p), supra note 2, at 358. I do not know how Dworkin would attempt to reconcile this with his suggestion that minimum-wage laws are not antecedently likely to give effect to external preferences. The assertion just quoted seems to me to make it impossible to argue that any right at all exists simply by virtue of the fact that legislation inconsistent with the supposed right would probably refiect external preferences.

There are other less important reasons for de-emphasizing the external-preference analysis. For one thing, the theory sketched in the text makes rights more fundamental. It seems truer to common intuitions about the reasons for protecting speech to say we protect it because the desire to speak is specially important than to say we protect it because laws restricting speech are specially likely to be passed for the wrong reasons. In practice, of course, most people support a constitutional protection for speech both because the desire to speak is special and because laws against speech are likely to be passed for the wrong reasons. But if we must choose between these arguments in defining the structure of our views at the most fundamental level, I suspect most people who "take rights seriously" would prefer the first explanation of rights to the second. (I do not mean to assert that we must choose. Perhaps the best theory of the sort we are considering will turn out to be one which both excludes certain preferences, such as external preferences, and gives certain other preferences special weight.)

The sketch in the text also makes better sense than the external-preferences approach of Dworkin's claim that rights are "anti-utilitarian". In the sketch, the existence of rights modifies the maximand of the utilitarian approach. In discussing external preferences, however, Dworkin suggests that the exclusion of external preferences is required by a correct understanding of utilitarianism itself. If that is so, then rights based on the external-preference argument are not really anti-utilitarian at all. They are practical protections against persistent political tendencies to depart from what utilitarianism requires. 
Dworkinian. Reading Dworkin's essays together, one cannot overlook the fact that, however complex some of his arguments, Dworkin wants to make the basic structure of his scheme of fundamental political values as simple as possible. The desire for simplicity and liberal predispositions together lead Dworkin to want to do just what our sketch does, namely, to put individual preferences at the center of things, with as little supporting machinery as possible. ${ }^{19}$

\section{B. Trump-Rights and Private Litigation}

One of Dworkin's central claims is that all litigation, properly understood, is about rights. So far as I am aware, Dworkin never specifically claims that all litigation involves "trump-rights", rights which satisfy the logic of rights developed in the preceding section. But he does sometimes seem to suggest this. For example, in rejecting the claim that Learned Hand's formulation of the test for negligence ${ }^{20}$ is a common-law doctrine based solely on the policy of efficiency, Dworkin asserts that Hand's test is a method of compromising competing abstract rights of the parties. ${ }^{21}$ Furthermore, the most explicit notion of rights in Dworkin is the notion of rights as trumps. If it is not trump-rights that are supposed to be involved in all litigation, Dworkin makes little effort to tell us explicitly what sort of rights he has in mind.

In this section I shall show that, despite the suggestions in Dworkin, much common-law litigation can not be understood as being about trump-rights. More specifically (and this specification is important in case the sketch of trump-rights in the preceding section is not fully acceptable to Dworkin), much common-law litigation can not be understood as being about rights which obey a logic justifying what I have referred to above as the "Lexington Avenue argument". ${ }^{22}$ The discussion which follows will center around negligence litigation and the Hand test. Other critics have objected to Dworkin's treatment of negligence, saying that if we sometimes compromise competing rights by appealing to policies, as we seem to do in this area, then the claim that litigation is always about rights loses its

19. Compare Righrs (p), supra note 2, at 367-68, where Dworkin suggests that the familiar antagonism between rights and collective welfare is a superficial manifestation of a fundamentally unified theory based on treatment as equals. Dworkin's notion of equality generates both the idea that everyone's preferences count and count equally (the goal of collective welfare) and the idea that certain preferences specially linked to individual dignity and autonomy deserve special weight (the goal of protecting rights).

20. United States v. Carroll Towing Co., 159 F.2d 169 (2d Cir. 1947).

21. Righrs (h), supra note 5, at 98-100.

22. See text at notes 6-8 supra. 
interest. ${ }^{23}$ I think that objection is somewhat off the mark, for reasons which will appear later in this essay. My own objection is stronger and narrower: stronger because I propose to show that as a logical matter we simply cannot view some areas of common-law litigation as involving trump-rights; narrower because I am prepared to admit, indeed to argue, that there may be other interesting senses in which common-law litigation is about rights after all.

Before proceeding, I should like to eliminate two possible sources of confusion. One is an argument that, for Dworkin, all litigation is about trump-rights. The other is an argument that private litigation could not possibly be about trump-rights.

As to the first, it might be suggested that in Dworkin's view a court is always obligated to pronounce whatever decision is required by the existing legal institutions. Furthermore, a court may not depart from whatever decision is required by existing institutions just because the general welfare (including the welfare of the parties to the case) would be marginally increased by doing so. In every case, then, the party who should prevail under existing institutions has a trump-right that the court decide in his favor. The party who should prevail has a trump-right that the judge enforce the law.

The argument just described does suggest a sense in which (at least for Dworkin, who believes in right answers) litigation always involves trump-rights. But Dworkin surely means more than this when he says that litigation involves rights. For one thing, if this is all he means, then his claim that litigation is about rights bears no relation to the idea that litigation is about rights more than about policy. We could perfectly well' assert on the one hand that some party has a trump-right that the law be enforced and on the other hand that the law involved even in private disputes is based exclusively on policy. If we want further evidence that Dworkin means something more than that one party has a trump-right that the law be enforced, we have only to look at what he says. In responding to the claim that the Hand test for negligence is based on policy instead of rights, Dworkin does not say, "Ah, but even so the party who should win under the Hand test has a right to a favorable decision." What he says is that the Hand test itself is a method of compromising competing rights.

As to the second possible confusion, it might be suggested that private litigation could not possibly involve trump-rights, because

23. E.g., Greenawalt, Policy, Rights, and Judicial Decision, 11 GA. L. Rey. 991, 1010-14, 1021-22 (1977); Note, Dworkin's "Rights Thesis," 77 Mich. L. Rev. 1167, 1179-83 (1976) (John Umana). 
trump-rights are rights against the state. Dworkin says that the notion of rights as trumps "marks the distinctive concept of an individual right against the State which is the heart . . . of constitutional theory in the United States."24 It might seem that unless trumprights are involved in private litigation in the manner we have just rejected, that is, as rights against the judge that the law be enforced, then they cannot be involved at all. But there is another way in which trump-rights can be involved in private litigation. Consider the law of assault. It seems plausible to suggest that an individual, in addition to having a trump-right not to be assaulted by agents of the state, also has a trump-right to be protected by the state from at least serious assaults by other citizens. If this is so, then the private law of assault presumably reflects that trump-right, at least in part, and litigation arising from private assaults will involve questions about the scope and implementation of that trump-right. It is in this sense, it seems to me, that Dworkin suggests trump-rights are involved in negligence litigation. ${ }^{25}$

We are now ready to consider the principal question, whether the common law of negligence can be understood as involving rights as trumps. Learned Hand's famous test for negligence was laid down in the Carroll Towing case. ${ }^{26}$ The issue in that case was whether a barge-owner could be held negligent on the ground that its bargee was not present on a barge moored to a pier, where the absence of the bargee was a contributing factor to damage that occurred after the barge slipped or was torn from its mooring. ${ }^{27}$ Hand's answer was that behavior is negligent if and only if it fails to maximize utility. Hand did not state his view in just those terms, but that is how he has been widely understood, and that is how Dworkin understands him. In effect, then, Dworkin says that even though the test of a defendant barge-owner's negligence in not having a bargee on board a moored barge is whether, in the circumstances, it would have been

24. Rights (h), supra note 5 , at 269 . It is perhaps worth noting that there can be nonconstitutional and non-trump-rights against the state, or at least against the government, such as the statutory rights at issue in much administrative-law litigation.

25. I do not suggest that all trump-rights against the state are or ought to be reflected in private litigation. It seems likely that in an affluent society with large disparities of wealth and income there is a trump-right to some degree of redistribution. Even so, we would think it improper for a judge to decide for plaintiff in a private-law case just because defendant was rich and a transfer of wealth from defendant to plaintiff would produce a more satisfactory distribution.

26. United States v. Carroll Towing Co., 159 F.2d 169 (2d Cir. 1947).

27. It was a plaintiff barge-owner whose ability to recover despite the absence of the bargee was at issue in Carroll Towing, but Hand obviously intended his test to be decisive of the negligence of a defendant barge-owner as well. Dworkin deals with Hand's formulation as a test of defendant's negligence, and so, for convenience, shall we. 
more productive of utility to have a bargee on board than not to, this test can still be understood as a method of compromising the competing abstract trump-rights of the barge-owner and others whose property an errant barge might damage. In this Dworkin is mistaken.

It is clear, I take it, that an appropriate legislative body could adopt the rule that a barge-owner is required to have a bargee on board a moored barge at all times. It is also clear, I assume, that the legislative body could adopt this rule with no other justification than that it marginally served the general interest. If these propositions are granted, then the barge-owner has no trump-right to dispense with a bargee on board. That is just an application of the Lexington Avenue argument. ${ }^{28}$ If the presence of a bargee can be required just to promote (marginally) the general welfare, then there is no trumpright to dispense with a bargee.

It is tempting to respond that Dworkin never claims there is a trump-right to dispense with a bargee. He relies rather (the response goes) on some broad abstract trump-right of the barge-owner to operate his barge, or more generally to manage his business or to use his property, as he sees fit. The fact that this abstract right may be subordinated to the general welfare in the specific context of the bargee-on-board problem does not mean that the abstract right does not exist. This response, while superficially plausible, is either mistaken or beside the,point. Assuming for the moment that the abstract right to operate one's barge as one sees fit (or whatever grander abstract right we might rely on) exists, either it is implicated in the bargee-onboard problem, or it is not. If it is not, then of course no solution of the bargee-on-board problem represents a compromise between abstract trump-rights, since one of the rights which is supposedly implicated is not implicated after all. If the right is implicated, then it cannot be denied just because denying it would be in the general interest. The reason is that if an abstract trump-right is implicated at all, it must be implicated as a trump-right, which means that it must retain the power to override some arguments based on the general interest. (Dworkin is fully aware of this, since this is a central argument of the essay "Taking Rights Seriously."29) In sum, if the bargee-on-board problem can be legislatively solved by a rule whose justification is simply that having a bargee on board at all times promotes the general welfare, then the bargee-on-board problem does

28. See text at notes 6-8 supra.

29. RIGHTS (h), supra note 5, at 197-204. 
not implicate any abstract trump-right of the defendant, of any description.

We have established that the bargee-on-board problem does not implicate any trump-right of a defendant barge-owner. That proposition has a further interesting consequence: If the bargee-on-board problem can properly be dealt with by applying Hand's "maximumutility" test for negligence, then it does not involve any trump-right on the plaintiff's side either. Under Hand's test, defendant loses if his behavior is not calculated to promote the general welfare. But also under Hand's test, defendant wins, and plaintiff loses, if defendant's behavior is calculated to promote the general welfare. Whatever interest plaintiff has is subordinated to marginal considerations of the general welfare. Therefore, by an application of the Lexington Avenue argument, whatever interest plaintiff has is not a trump-right. It turns out that the bargee-on-board problem involves no trump-right on either side.

Note that the argument that plaintiff has no trump-right depends on the prior conclusion that defendant has no trump-right. If there were a trump-right of defendant's involved in the case, we could say plaintiff's right was being subordinated to the right of the defendant. But since there is no trump-right on the defendant's side, the plaintiff's supposed trump-right is being subordinated to the general interest alone (including, of course, the "general interest" of the defendant) and is shown not to be a trump-right by that fact.

We have just seen that the argument that plaintiff has no trumpright depends on defendant's having none. That suggests a possible objection to the original argument that defendant has no trumpright. The original argument turned on the assumption that defendant could be required to have a bargee on board on the sole ground that such a requirement would marginally promote the public interest. It might now be objected that this assumption was unjustified. To be sure, the objection runs, defendant can be required to have a bargee on board. But our clear intuition that this is possible implicitly assumes that the point of the requirement is to protect the rights of potential plaintiffs not to suffer damage from errant barges. Our intuition that the regulation is justifiable is therefore not an intuition that the regulation can be justified by appeal solely to the general welfare.

This objection is formally on point. If our belief that the defendant can be required to have a bargee on board depended on the implicit assumption that this was being done to protect the trump-rights of potential plaintiffs, then the argument that defendant had no 
trump-right would collapse. But reflection will reveal that we do not think the requirement of a bargee on board can be justified only as a protection for potential plaintiffs in damage suits. Even if there were no significant risk of damage caused by having no bargee on board, the presence of a bargee could be required if it would merely facilitate the movement of traffic in and out of slips where barges are moored. For that matter, the legislature could require the presence of a bargee on board just as a feather-bedding measure passed at the behest of the bargemen's union. We conclude that there is indeed no trump-right which protects the barge-owner's preference for not having a bargee on board. ${ }^{30}$

We have shown that there are no trump-rights, not even abstract ones, at issue in private litigation where plaintiff's claim is based on defendant's alleged negligence in not having a bargee on board a barge. The same argument would suffice to show that there are no trump-rights at issue in many, if not most, ordinary negligence cases. I believe that the same argument could be used to show that no trump-rights are implicated in much private litigation over property rights. Dworkin has admitted that conflicts between "rights" arising in connection with the institution of property are often settled by appeals to the general welfare. ${ }^{31}$ This fact by itself does not show that the "rights" at issue are not trump-rights. But it does show that they are not trump-rights if it is also true that the defendant's behavior is of a sort which could be regulated by statute just to produce a marginal increase in the general welfare.

I think we are justified in concluding that there are large areas of traditional private litigation which do not involve trump-rights at all. If all private litigation involves "rights," as Dworkin claims, then they must be "rights" of some other sort."32

30. The objection considered in the text does suggest an interesting point. If there were a regulation requiring a bargee on board, and if it were clear that this measure had been passed solely for the convenience of traffic, or for feather-bedding, then the regulation might well not be regarded as making the absence of a bargee negligence per se in a private suit for damages from an errant barge. This insulation of private litigation from the effects of some rules adopted solely to promote the general welfare is an interesting phenomenon, and it may well be related to other features of private litigation discussed in the remainder of this essay. But it has no effect on the argument that defendant has no trump-right and that plaintiff therefore has none either.

31. Rights (p), supra note 2, at 300-01; Seven Critics, supra note 5, at 1211.

32. The following point is worth noting: While Dworkin says that the plaintiff's right involved in cases like Carroll Towing is the right to be treated with the minimal respect due a human being, RIGHTS (h), supra note 5, at 98 , he does not specify what right of the defendant is supposed to be in issue. The closest he comes to specifying the defendant's right is a reference to the "liberty of those from whom [is demanded] an unstated level of concern and respect." Id. But it is a central contention of "What Rights Do We Have?" that there is no trump-right to liberty in general. Id. at 266-72. The argument in "What Rights?" is correct. 


\section{Rights as Individuated Claims}

If we return to our text, we will discover that there is an aspect of rights which Dworkin emphasizes nearly as much as the idea that rights are trumps. That is the idea that rights are individuated political aims. ${ }^{33}$ In saying that rights are individuated political aims, Dworkin seems to mean something more than the truism, as Raz calls it, that rights have right-holders. Does this suggest anything about the sense in which private litigation involves rights?

It is a fact, a fact so obvious as to be easily overlooked, that in the standard common-law case the plaintiff comes before the court citing a specialized harm to himself, either accomplished or threatened. For example, every law student learns that a cause of action in negligence requires "[1] a breach [2] of a duty that [3] causes [4] harm." Similarly, every law student learns that physical harm is not required in cases involving intentional torts like assault because of the injury to plaintiff's dignity; or that in many kinds of defamation cases damage is presumed, whereas in a few it must be proved; 34 or that actual harm is not required in cases of trespass to land because of the need for an action to try title. The paradigm seems clearly to be that in order to state a cause of action plaintiff must explain (among other things) how he has suffered from defendant's behavior. In the case of a plaintiff whose leg was broken in an automobile accident, there is no problem. In the case of a plaintiff who has been assaulted but not injured physically, we make special mention of a less obvious injury, to plaintiff's dignity. In defamation cases in which proof of harm is not required, it is not because harm is irrelevant, but because it is "presumed". In the case of trespass to land, we recognize the need for an explanation of why there is a cause of action even when there is no harm of any usual sort, either actual or presumed.

Dworkin does not point to any genuine trump-right of defendant which is involved in Carroll Towing because, as we have seen, there is none.

It might be suggested that there is a quite different right of defendant involved, the right not to have money taken from him to enrich someone else. It is true that we think the government could not order defendant to pay plaintiff a specified sum simply because the transfer would promote the general interest. In that sense there is a trump-right not to have money taken. But we have no doubt that defendant can be required to pay for damage he has (proximately?) caused in cases like Carroll Towing if a rule imposing liability would promote the general interest. Somehow, then, the trump-right not to have money taken away is not implicated when the question is whether money should be taken from defendant to compensate plaintiff for harm defendant has caused. There are interesting complications here which I shall not pursue, since Dworkin nowhere clearly relies on defendant's right not to have money taken away. The fleeting suggestion of such a right, $i d$. at 85 , raises more problems than it settles.

33. E.g., id. at 91 .

34. The text describes the state of the law of defamation before Gertz v. Robert Welch, Inc., 418 U.S. 323 (1974). I make no attempt to assess the impact of that case, beyond noting that it extends the requirement of proof of harm. 
Needless to say, if there is a statute authorizing actions by plaintiffs who have suffered no special harm, or who can prove none, then there is no bar to the court's hearing a case brought under the statute. Indeed, the court must do so. ${ }^{35}$ Dworkin rarely focusses on statutory problems, and he plainly assumes that the claim that statutory litigation is about rights is not controversial. I am not entirely comfortable with that. I should like to know more about just how statutes create rights, and just what sort of things statutory rights are. But Dworkin is probably correct that few of his readers would object to the idea that statutes create rights. I shall therefore concentrate, in the remainder of this section, on plaintiffs who do not rely on a statute. ${ }^{36}$

We can find more evidence for the claim that common-law causes of action normally require a showing of specialized harm to the plaintiff if we return to the Carroll Towing context. Suppose that the absence of bargees from moored barges creates no significant risk of damage to any property, but that it does injure the general welfare by slowing somewhat the movement of harbor traffic: If there is no relevant statute or port authority regulation, an ordinary citizen of the harbor town, one who has no special connection with the operations of the harbor, cannot go to court and seek an injunction requiring some named barge-owner to man his moored barges. Nor, for that matter, can a ship-owner whose vessels use the harbor regularly.

35. It might be suggested that a statute authorizing suit in a court of the United States by a private individual who had suffered no harm would raise constitutional problems. The constitutional law of standing involves complexities which are obviously not relevant here, and I shall ignore this matter.

36. It is perhaps worth noting that even though statutes can create causes of action in plaintiffs who have suffered no harm, they rarely do so. Most statutory causes of action, at least against private defendants, either require a showing of harm or else stipulate as the basis for liability behavior from which some harm is easily presumed. It is an interesting question why this should be so, why we make so little use of "private attorneys general". The principal reasons I shall suggest below for requiring plaintiffs to show specialized harm in the absence of a statute do not support the same limitation on statutory causes of action.

There are a number of possible reasons for the general requirement of harrn even in statutory cases. One is that the legislature is concerned to prevent wasteful or spiteful litigation. Another is that the legislature is influenced, consciously or unconsciously, in the formulation of statutory causes of action by the paradigm of a "standard" common-law cause of action.

Yet another possibility is that even statutes are often not intended as firm rules for how persons shall behave so much as they are intended as negotiable (in effect) rules for localized "sub-games" in the large game of social behavior. The much-maligned "zone of protected interests" test for standing to complain of administrative decisions, see generally J. VINING, LEGAL IDENTITY 34-39 (1978), may be explained on that ground. If the legislature contemplates that the process of administrative oversight of a regulated activity will be one of bargaining and give-and-take between the agency and the parties regulated, then allowing unregulated parties only incidentally affected to challenge administrative decisions might upset a delicate balance for no reason the legislature regards as significant. This is not a standard view of the administrative process, but it is a realistic one in some respects and may be part of a better theory than any we now have. 
If all the plaintiff ship-owner can say is that everything would run a bit more smoothly if defendant manned his moored barges, and that plaintiff is inconvenienced by defendant's refusal in the same manner and measure as everyone else who uses the harbor, then plaintiff will be held not to have raised an issue which makes a claim on the court's attention (beyond the attention required to dismiss the complaint). Plaintiff cannot come before the court and argue simply that defendant's behavior is inefficient or otherwise damaging to the general welfare.

Note that I do not say plaintiff must claim a harm to himself which is greater than or different from the harm to anyone else. I say only that plaintiff must claim a harm to himself which is greater than or different from the harms distributed over society at large. This is obviously a matter of degree, and there are borderline cases. But the basic point is clear. Courts do not exist for the redress of claims based solely on considerations of the general welfare. ${ }^{37}$

It is worth asking why courts do not listen to plaintiffs who base their claims solely on the general welfare. The most obvious answer is that we do not think courts are well suited to deal with questions about what promotes the general welfare. But this answer ignores what even Dworkin admits, that courts do and should decide cases on policy grounds if these grounds are somehow implicated in questions about "rights."

A somewhat more sophisticated answer is that we do not need courts to listen to "non-traditional" plaintiffs, plaintiffs who claim no specialized harm. If the only losses from defendant's behavior are relatively slight ones spread widely over the citizenry (and this is the practical precondition for the absence of a "traditional" plaintiff who has suffered specialized harm), then either the legislature will be moved by broad-based political pressure to do something about defendant's behavior, or else the problem is not serious enough to worry about. ${ }^{38}$

37. Needless to say, a plaintiff who relies on a statute does not rely solely on the general welfare, even if that is what the statute is based on.

38. The argument $I$ suggest in the text about why courts do not hear claims based solely on the general welfare is the same argument the Supreme Court used to deny standing in United States v. Richardson, 418 U.S. 166 (1974), and Schlesinger v. Reservists Committee To Stop the War, 418 U.S. 208 (1974). I feel constrained therefore to explain why the argument is not a good one in the context in which the Court applied it, that is, when the issue is standing to raise a constitutional question.

The argument I made in the text assumes that the legislature can be counted on to pursue the general welfare. But with regard to any particular prescription for legislative behavior which is included in the Constitution, the mere fact of inclusion suggests that the prescription in question is one which the legislature cannot be counted on to follow if left to its own devices. Furthermore, although we tend to think of constitutional provisions as intrinsically anti- 
Another possible reason for not listening to a plaintiff who claims no special harm (and who does not rely on a statute) is that the defendant is specially likely to be surprised if a court rules against him at the instance of such a plaintiff. The reason is not just that defendant will be surprised if the court entertains a case against him by a non-traditional plaintiff when non-traditional plaintiffs are not generally listened to. Surprise from this source can be avoided by making it clear that non-traditional plaintiffs will be heard. The reason is that even if it is understood that non-traditional plaintiffs will be heard, it may be harder for defendant to anticipate that his behavior will create a case for a non-traditional plaintiff than to anticipate that it will create a case for a traditional plaintiff. Defendants may not be as well-placed to identify the general social consequences of their behavior as they are to identify significant threatened harms to individual potential plaintiffs. Courts cannot always avoid surprising litigants, but surprise is a bad thing, and in addition to being more likely, it may be less defensible where the only harm defendant does is to general social interests. ${ }^{39}$

I have pointed out that courts do not ordinarily listen to plaintiffs who claim no special harm to themselves, and I have offered some suggestions about why this might be so. We can interpret Dworkin's assertion that private litigation is about rights as an assertion that private litigation is based on individuated claims, claims arising either from specialized harm or else from a statute. ${ }^{40}$ There is a prob-

majoritarian and to regard provisions which do not protect particularized interests as being of secondary importance, this view is too narrow. The Framers of the Constitution were interested in protecting the majority as well as minorities. The fear in pre-Revolutionary times of "corruption" of the legislature by the executive is well-documented, and the recognition by 1787 of the need for an executive branch with substantial powers hardly suggests that that fear was forgotten. The provisions at issue in Richardson and Schlesinger (especially the latter) can be seen as aimed at least in part at preventing this corruption. If that is the point of the provisions, then leaving the enforcement to Congress is like leaving a suggestible child to guard the cookie-jar against a smooth-talking older sibling who offers to share the booty from an illicit raid.

39. I confess that although I have the feeling that surprising the defendant is more objectionable where the defendant harms only the general interest, as opposed to inflicting specialized harm on some particular plaintiff, I am not sure why this should be so. The one possible reason that occurs to me is the following. Where there is a plaintiff who has suffered specialized harm, that plaintiff has in all probability been "surprised." The choice then is either to leave the loss on the surprised plaintiff or else to transfer it to a surprised defendant. If, on the other hand, there is no plaintiff who has suffered specialized harm, then the total surprise is minimized by avoiding surprise to the defendant.

It might be said that surprise to the defendant can be avoided by making the court's decision prospective. Indeed, it might be said that if there is no traditional plaintiff, the only likely remedy is an injunction. But even injunctions, though they are prospective in a sense, controlling only future behavior, alter the returns from past behavior and injure expectations. And money may be at stake if the defendant is liable for attorney's fees or costs.

40. I ignore the possibility of claims against private individuals based directly on the Constitution. After United States v. Guest, 383 U.S. 745 (1966) (the Constitution protects the right 
lem with this, however. It does not follow from the fact that courts may not entertain claims based on the general welfare (that is, based neither on specialized harm nor on a statute) that courts may not attend to any and all arguments based on the general welfare in those cases which merit their attention for other reasons. The assertion that private litigation is about rights as individuated claims seems to be an assertion about "standing" which tells us nothing about what arguments are admissible, or about what a court is supposed to do with a standard "hard case". I think there is more than we have yet discovered in the idea that private litigation involves rights as individuated claims, but whatever else there is is elusive. I shall not try to pin it down just yet.

It is appropriate to conclude this part of the essay by noting a few connections, more phenomenological than logical, between the idea of rights as trumps and the idea of rights as individuated claims.

First, there is a natural tendency to slide from the perception that private litigation involves rights in the sense of individuated claims to the notion that private litigation involves rights in the sense of trumps. A private plaintiff who sues a private defendant ordinarily has suffered or is threatened with some significant harm. Now, it is widely felt that avoiding harm is more important than promoting increases in welfare. In particular, it is widely felt that it is unfair to require a few individuals to suffer significant specialized harms in order to produce widespread benefits, even if the total benefit exceeds the total harm. In a theory which reflects these feelings, the "right" not to suffer harm functions as a trump. Preferences for not suffering particularized harms are accorded special weight. Because of this special weight given to avoiding harm, rights in the sense of individuated claims are also rights in the sense of trumps. I shall refer to this connection by the convenient, if crude, sobriquet "lumps as trumps".

It may seem that by introducing the idea of lumps as trumps, I have given a reason to believe that all ordinary common-law litigation, based on particularized harms, involves trump-rights after all, and that $I$ have thereby contradicted the conclusion of the previous section. That is not the case. What $I$ have shown is that in a legal regime which fully respected the intuition that avoiding harm de-

to travel against private interference), and Bivens v. Six Unknown Named Agents, 403 U.S. 388 (1971) (the Constitution itself creates action for damages against federal officials for fourth amendment violations), the possibility of an action against a purely private defendant based directly on the Constitution cannot be dismissed. But any such cause of action would be a curiosity. 
serves special weight, all common-law litigation would involve trump-rights. But, precisely because of elements like the Hand test for negligence, our present regime does not fully respect that intuition. Under the Hand test, if defendant's behavior promotes the general welfare, the costs are allowed to fall where they may. Probably we are moving in the direction of greater respect for the intuition that avoiding harm deserves special weight. An important factor (not necessarily the most important factor) in the rise of strict liability has been that it tends to treat lumps as trumps. But even if it is dying, the Hand view is not yet dead. It is not yet the case that common-law litigation always involves rights as trumps.

The idea of lumps as trumps suggests an insight into Dworkin's claim, which has troubled critics, that when an argument of policy is translated into an argument of principle it ordinarily loses force in the translation. ${ }^{41}$ Dworkin's point, I suggest, is quite simple. If we are considering a policy argument about a complex matter with widespread social ramifications, then most of the harms or benefits which figure in the policy argument will be small and ordinary. They will not involve preferences which are protected by trumprights such as the right to speak or the right to have an abortion. Furthermore, to the extent the argument depends on avoidance of harms, most of the harms involved will not be sufficiently large or specialized to involve rights as individuated claims, even if the relevant political theory has a principle about avoidance of large harms which transforms rights as individuated claims into rights as trumps. In short, most of the harms and benefits which figure in the policy argument drop out when we consider the rights-based argument that can be manufactured from the same social consequences, and the extra weight that some of them acquire when treated as trumps is not enough to make up the difference.

I have one final observation, unrelated to the "lumps as trumps" idea. I have noted previously that there is no abstract trump-right to use one's property as one sees fit (or that if there is one, it is not implicated in many concrete situations where the breadth of the rubric would lead us to expect it to be implicated). 42 We are nonetheless strongly inclined to talk as if there were such a right. The idea of rights as individuated claims may explain why. It may be that when we say an owner has the right to use his property as he sees fit, we are calling attention to the fact that (in the absence of a statute) no

41. For Dworkin's claim, see RIGHTS (h), supra note 5, at 96. For a troubled critic, see Greenawalt, supra note 23, at 1016-26.

42. See text accompanying notes $28-30$ supra, see also note 32 supra. 
other private individual will be heard to complain about how the property is used unless that other individual has been specially harmed. This is a significant protection for the property-owner, even though it falls short of being a trump-right.

\section{PRINCIPLES AND Policies}

The principal results of the discussion to this point are the following: (1) we have sketched the logic of rights as trumps; (2) we have shown that not all private litigation involves trump-rights; and (3) we have suggested that all private litigation may involve rights understood as individuated claims created either by statute or by the occurrence of specialized harm. We have also observed that even if private litigation involves rights in the sense of individuated claims, it is not obvious that anything follows about what arguments judges may appropriately consider in deciding hard cases. The notion of rights as individuated claims speaks to the issue of what cases courts should hear, and not, it would seem, to the issue of how courts should decide the cases they do hear.

This brief summary indicates a new problem. Dworkin claims that judges must consider only arguments of principle, not arguments of policy, and he defines arguments of principle as arguments about rights. ${ }^{43}$ But what we have learned so far about rights is not an adequate basis for any distinction between arguments of principle and arguments of policy. We have seen that the rights involved in common-law cases are not limited to trump-rights. That means that if common-law adjudication relies only on arguments of principle, then arguments of principle must include more than arguments about trump-rights. How much more? The only other notion of rights we have uncovered is the notion of rights as individuated claims. Now, if all private litigation is about rights provided it involves individuated claims, and if any argument offered on the issue of whether someone has a right is an argument of principle, it might seem to follow that any argument made to a court in litigation arising from an individuated claim is an argument about rights and

43. Righrs (p), supra note 2, at 297; Seven Critics, supra note 5, at 1207. See also Rights (h), supra note 5, at 100 . In elaborating the claim that courts should consider only arguments of principle, Dworkin admits that judges may sometimes consider arguments about widespread social consequences and other arguments based on what we would normally regard as policies. E.g., id. at 107-10 (policy embodied in statute); RigHTs (p), supra note 2, at 300-01; Seven Critics, supra note 5, at 1211 (policy made relevant by conventional morality); RiGHTs (h), supra note 5, at 314-15; Seven Critics, supra note 5, at 1226-27 (policy part of point of a social institution). But he insists that as long as the underlying question is one of rights, the "policy" considerations are transformed into arguments of principle. 
becomes ipso facto an argument of principle. We need not pause over the somewhat dubious logic of this suggestion. Plainly it is not - what Dworkin has in mind. But it does pinpoint the problem. Dworkin defines arguments of principle as arguments about rights, but the only notion of rights we have found so far that is consistent with his claim that private litigation is about rights is a notion which is of no use when it comes to admitting some arguments and excluding others.

If we are going to make sense of Dworkin's principle/policy distinction, we must infer what the distinction is from his arguments about why it matters. With that in mind, we shall plunge ahead into Dworkin's arguments about why courts rely only on principle, even though these arguments assume a distinction we do not yet understand. If we succeed in making something of the principle/policy distinction, we will presumably be uncovering a new notion of rights at the same time. Or at least, and I think I prefer this characterization, we will be giving some new content to the ideas of rights as individuated claims.

\section{A. Principles, Policies, and Consistency}

There is an argument in Dworkin which runs as follows: Courts are subject to a strong requirement of articulate consistency. They must explain, without relying on arbitrary distinctions, how their decisions treat like cases alike. In general, political decisions based on principle must treat like cases alike, but political decisions based on policy need not (or need not to the same extent). If courts could properly base their decisions on policy, then it would be impossible to account for the importance we attach to articulate consistency in judicial decision. Therefore it must be that courts can properly base decisions only on arguments of principle. Q.E.D. ${ }^{44}$

Undeniably courts are subject to a strong requirement of consistency. Also undeniably, legislatures (or legislators, if that is the appropriate comparison) are not held to the same standard. Why there should be this difference is an important question. But the argument just outlined is a very problematical answer because of its reliance on the notion that decisions based on policy need not treat like cases alike.

Dworkin's claim that decisions made on grounds of policy need not treat like cases alike is puzzling, and it has not gone uncriticized.

44. The variants of this argument include but are not limited to Dworkin's arguments about the "gravitational force" of precedent. 
Unfortunately, both Dworkin and his critics rely largely on assertion and on examples which are either flatly unconvincing or else leave one wondering whether they really go to the heart of the problem. I think there is some truth on both sides. To see why, we must spend some time clarifying the issues.

First off, we note that Dworkin acknowledges a variety of restrictions on decisions based on policy: (1) they must not be irrational; (2) they must not violate independent rights (as would a program providing a subsidy only to newspapers with certain political views); (3) they must not be used as a cover for discrimination against weak or unpopular groups [this restriction could be viewed as included in (2), but Dworkin mentions it separately]; (4) they must not impose excessive burdens on particular individuals or particular sections of the community. 45 But Dworkin goes on to say that:

If a legislative decision benefits some particular group, not because that group is thought entitled to the benefit, but because the benefit is a by-product of a scheme thought to advance a particular collective goal, then others have no political right to the same benefit, even if providing that benefit for them would, in fact, advance that same collective goal even further. ${ }^{46}$

In short, there seems to be no right that like cases be treated alike in the distribution of benefits to which the recipients are not entitled (or to which they are not entitled independently of the legislative decision in question). The problem we shall focus on, then, is the problem of fairness in the distribution of benefits incidental to the promotion of some general social goal.

We should also keep in mind that Dworkin's real position is less extreme than he sometimes suggests. There are passages, including the passage just quoted, in which Dworkin intimates that there is no requirement of consistency in decisions of policy conferring benefits. ${ }^{47}$ But when he is being careful he says rather that the requirement of consistency in such decisions is "relatively weak"48 or makes "slight demands".49 Indeed, Dworkin and his critics seem to agree that at some level the proposition that like cases should be treated alike is a truism. ${ }^{50}$ Even so, there is disagreement about the strength of the requirement of consistency. Against Dworkin's claim that the

45. Rights (p), supra note 2, at 320-21; Seven Critics, supra note 5, at 1233.

46. Rights (p), supra note 2, at 321; Seven Critics, supra note 5, at 1233-34.

47. See also RigHTs (h), supra note 5 , at 113 (the full paragraph in mid-page).

48. Id. at 88.

49. Id. at 113

50. For Dworkin, see Rights (p), supra note 2, at 319; Seven Critics, supra note 5, at 1232. For the critics, see passages cited in text at notes 51-52 infra. 
requirement is "relatively weak," Greenawalt says that "[t]he conferral of benefits for policy reasons typically gives rise to a substantial claim of justice to equal treatment on behalf of those similarly situated."S1 Raz writes that "the requirements of consistency apply with equal force and in the same way to rights and goals." 52

Even if we keep in mind the points made so far, there are respects in which Dworkin's arguments and examples tend to confuse as much as they clarify. One problem is that Dworkin, since he believes that only legislatures should make decisions based on policy, ${ }^{53}$ considers as examples of decisions based on policy only decisions made by the legislature. The result is that even if we agree that the requirements of consistency are weak in Dworkin's exemplary situations, we may feel that what is manifested is not a weak requirement of consistency for decisions made on the basis of policy, but rather a weak requirement of consistency for decisions made by the legislature. This objection might be answered if Dworkin compared with his examples of legislative policy decisions some examples of legislative decisions based on principle. But he does not do this, or does not do it explicitly enough.

It is clear that we do expect less consistency from the legislature than from courts. And this fact requires some explanation. We could possibly construe Dworkin as arguing that we should accept, as the most plausible explanation for this undoubted fact, a package of two propositions, namely (1) that courts, unlike legislatures, are restricted to arguments of principle and (2) that decisions based on principle are intrinsically more subject to the requirement of consistency than decisions based on policy. If this were Dworkin's argument, then it would be formally unimpeachable, but it would reveal its weakness on its face. There is a limit to how much we will swallow all at once on the basis of a "most plausible explanation" argument. Instead, Dworkin plainly intends at some points to be giving independent evidence for the second of the two propositions mentioned above, so that only the first proposition will have to be accepted on "most plausible explanation" grounds. But his examples are unconvincing as evidence for the second proposition precisely because they may be evidence of nothing more than the as-yet-unex-

51. Greenawalt, supra note 23 , at 1008.

52. 'Raz, supra note 1 , at 135 .

53. Perhaps it would be more accurate to say that, for Dworkin, only the legislature should make decisions based on "pure" policy, since courts may consider arguments of policy in contexts which make them "really" arguments of principle. See note 43 supra. 
plained difference between legislatures and courts. ${ }^{54}$

Another difficulty with Dworkin's discussion is that many of his examples involve the issue of whether the granting of a benefit to one person or group requires the granting of a similar benefit to a different person or group at a later time. This is problematic because we may feel that all kinds of political decisions (decisions of principle as well as decisions of policy) are subject to weaker requirements of consistency-over-time than of consistency-between-different-persons-at-the-same-time. Thus, in discussing his "theory of mistakes," Dworkin writes:

[T] he main force of the underlying argument of fairness is forwardlooking, not backward-looking. The gravitational force of Mrs. MacPherson's case depends not simply on the fact that she recovered for her Buick, but also on the fact that the government proposes to allow others in just her position to recover in the future. If the courts proposed to overrule the decision, no substantial argument of fairness, fixing on the actual decision in the case, survives in favor of the plaintiff in [a later similar case]. .5

Here, of course, Dworkin is denigrating the importance of consistency-over-time even in the application of principle. I do not mean to suggest that there is no requirement of consistency-over-time, either in decisions of principle or in decisions of policy. I suggest only

54. Note that the criticism in the text is not the same as Greenawalt's complaint that Dworkin uses examples involving legislative subsidies. Greenawalt, supra note 23, at 1008-09. Dworkin's response that any benefit conferred as a by-product of an attempt to promote the general interest, even under rules of general application, is in effect a subsidy, RiGHTS (p), supra note 2, at 320; Seven Critics, supra note 5, at 1232-33, is persuasive against Greenawalt's criticism. But it has no force against mine, since the examples Dworkin uses against Greenawalt still all involve legislative decisions.

Lest my criticism be thought captious, I shall give an example which reveals a difference between what we expect from legislatures and what we expect from courts that plainly does not depend on any difference between principles and policies. Supposing MacPherson v. Buick Motor Co., 217 N.Y. 382, 111 N.E. 1050 (1916), had not been decided, the legislature could enact the rule of MacPherson for the automobile industry without enacting a similar rule for washing machines. They could do this on the sole ground that they had special evidence of the irresponsibility of automobile manufacturers in refusing to settle morally meritorious claims out of court, a ground which surely would not justify a court in having a special rule for automobiles. Indeed, if the legislature were concerned lest the pressure of common-law development under the influence of the new statutory rule for automobiles should eliminate the distinction between automobile and washing-machine manufacturers, they could, at the same time they enact the new rule for automobiles, enact the old rule (of manufacturer non-liability in the absence of privity) for washing machines. They might do this on the ground that washing-machine manufacturers had a good record of satisfying morally meritorious claims without litigation, while purchasers of washing machines were demonstrably prone to bring unfounded and spiteful suits against their vendors. All of the reasons for legislative action which I have mentioned involve the protection of rights, either the rights of purchasers or the rights of manufacturers. Nonetheless, we would not think it appropriate for a court to draw a line between automobile manufacturers and washing-machine manufacturers and justify it on these grounds. We see that even in the pursuit of rights, the legislature can appropriately draw lines in a way the courts cannot.

55. Rights (h), supra note 5, at 118. 
that time is a complicating factor and that Dworkin's frequent inattention to the importance of time makes it harder to decide just what he manages to prove.

Despite my objections to Dworkin's exposition, I think he has a point, which I shall attempt to elucidate by discussing some examples of my own. Note that what follows is not a complete discussion of the extent to which decisions of policy are constrained by the requirement of consistency. What $I$ offer is only a suggestion about what Dworkin might plausibly mean when he says that decisions of policy and decisions of principle differ in respect of this requirement.

Let us suppose a kingdom in which there are ten thousand subjects, ruled by Rex. One day Rex says to us: "The economy is in need of stimulation. I have decided to select a thousand of my subjects at random and give each subject so selected a thousand dollars." We might suggest that it would be fairer to give a thousand dollars to all ten thousand subjects, instead of giving that amount to only one thousand subjects selected at random. Or we might suggest that if Rex has only a million dollars to distribute, he would do better to give each of his ten thousand subjects one hundred dollars. But Rex might respond:

It is a well-known economic fact, in my kingdom, that a windfall of less than a thousand dollars will not affect the spending of any subject, though the effect of a thousand dollars is significant. Because of this threshold, it is not possible to stimulate the economy at all, at least in the short run, with gifts of under a thousand dollars. On the other hand, the total stimulation that is required is only a million dollars' worth. Greater stimulation would cause the economy to 'overheat', as my advisers are fond of saying. So I have proposed the most equitable distribution of largesse possible consistent with the needs of the economy and the possibilities for influencing it.

At this point we might try to convince Rex that equal treatment of his subjects is more important than either stimulating or not overheating the economy, and that he should for that reason either give nothing or else give the same thousand dollars to each of his subjects. But we would recognize that Rex's position has a satisfactory internal logic of its own. If he disagrees with us about the relative importance of equal treatment and of effective fiscal policy, we would not regard him as irrational.

Let us now compare with this economic stimulation program a different program from exactly the same source. One day Rex says to us: "I have just realized that there is a moral right of free speech. I have decided to select a thousand of my subjects at random and protect them in the exercise of that right." This would be exceedingly 
odd. It seems to me that Rex's free-speech proposal is not merely unfair, but downright irrational. I hope the reader will at least agree with me at the outset that the free-speech program seems somehow more objectionable than the economic stimulation program. If the existence of some difference between the programs is conceded, I can attempt to explain what the difference is.

To say that there is a right of free speech is to say that for each individual subject, there is a reason for protecting that subject in his desire to speak. If there is a reason for protecting each individual subject in his desire to speak, then it is irrational (absent some citation of countervailing reasons) to protect a thousand subjects and ignore the other nine thousand. Indeed, it would be irrational to protect nine thousand nine hundred ninety-nine and ignore the other one. There is a sense in which the need for economic stimulation also provides a reason for giving a thousand dollars to each individual subject (assuming that all subjects have the same propensity to spend windfall income). But there is a difference between the sorts of reasons involved in the two cases. The reason for giving money to each subject in the economic stimulation program is what we might call an "index-dependent reason". The strength of the reason for giving money to any particular subject depends on the number of other subjects to whom it has already been decided that money shall be given. In the precise case before us, the reason for giving out money vanishes entirely at some point, to be replaced by a reason for not giving out any more. Rex's reason for protecting speech, however, is what we might call an "index-free reason". The strength of the reason is the same for the ten-thousandth subject as for the first. 56

I have said that Rex's reason for protecting speech is an indexfree reason, and I think that is the natural way to take the statement I put into Rex's mouth describing his free-speech proposal. I do not assert that all possible reasons for protecting speech are index-free. If the reason for protecting speech is to promote the discovery of truth, or to provide a check on governmental misbehavior, then it is likely that the return from protecting the last thousand subjects is less than the return from protecting the first thousand. These reasons for protecting speech are index-dependent. But if the reason for protecting speech is either of those suggested, then we have not really recognized a right to speech at all. We have decided to protect

56. I ignore, for the sake of simplicity, the possibility that there might be index-dependent costs associated with protecting speech, that is, that the marginal social cost of protection might vary with the number of speakers who are protected. 
speech in the pursuit of a social goal. To recognize a right to speech, as we ordinarily use the term, is precisely to posit an individual-centered reason for protecting speech, a reason which does not diminish in strength as more and more individuals are protected. In sum, speech may be protected without being recognized as a right; but if it is recognized as a right, then the reason for protecting speech represented by the right is index-free. ${ }^{57}$

Just as there can be index-dependent reasons for protecting speech, so there might, at least as a theoretical possibility, be indexfree reasons which do not apply to all persons. It is conceivable (though unlikely) that someone could establish the existence of a right to free speech belonging, say, to all persons over six feet tall and to no one else. The reason for protecting speech provided by such a right would not be index-dependent, since the strength of the reason would not depend on the number of persons protected. On the other hand, if Rex's reason for protecting speech were the existence of this right, then he would not be behaving irrationally if he protected only those of his subjects whose height was over six feet. In suggesting that Rex cannot rationally protect the desire to speak of some of his subjects without protecting the same desire for all of them, I have been assuming that any right to speak must be a universal right. It must belong to all Rex's subjects or to none of them. ${ }^{58}$

It may strike the reader as odd that I now say I have been assuming that the right to speak is a universal right. I set out a few paragraphs back to explain why it is irrational for Rex to protect only a thousand subjects in his free-speech program. It might seem that if $I$ had just begun by pointing out my assumption that the right to speak was universal, then, aside from the possibility of questioning the assumption, nothing more need have been said. Plausible as this sounds, it suggests that matters are simpler than they are.

Our original goal, remember, was to explain the difference be-

57. It might be objected, against what I say in the text, that some people would justify some constitutional rights, including perhaps the right to speak, entirely in terms of social goals such as the discovery of truth, and that people who take this line are not talking nonsense, so that my equation of "rights" with individual-centered or index-free reasons is incorrect. The objection is misguided. If we give speech constitutional protection in order to achieve general social goals, we are not recognizing a theoretically fundamental right to speak. We are positing a right to speak at the level of constitutional analysis. But at that level we are also committed, by our use of the language of rights, to regarding the posited reason for protecting speech as index-free. Some further complications are dealt with in the text which follows, but I believe the reader will see that the objection outlined at the beginning of this note vanishes if we are careful to check the designation of something as a right against its operative logic at the same level of analysis.

58. I ignore the problem of children, incompetents, and so on. Compare Dworkin's assumption that all political rights are universal, Rights (h), supra note 5, at 94 n.1. 
tween Rex's economic-stimulation plan and his free-speech plan. The universality of the right to speak is not enough to explain this difference. The assertion that the right to speak is a universal right would seem to mean that, with regard to the right to speak, all Rex's subjects are indistinguishable. Whatever differences there may be between subjects, those differences are not relevant to who should be allowed to speak and who should not. But the reason for giving each subject a thousand dollars under the economic-stimulation plan was also a "universal" reason. We assumed that there were no differences between individual subjects in their propensity to spend windfall income. 59 In other words, subjects were indistinguishable with regard to the assignment of roles in the economic-stimulation program until Rex (justifiably) created some distinctions by his random selection process. That Rex was justified in creating some distinctions in one program but not in the other reflects, of course, a genuine difference between the programs. But the difference is not the universality of the right to speak.

In general, if Rex sets out to pursue a social goal like economic stimulation, he cannot safely assume either that all of his subjects are indistinguishable with respect to the roles they can play in a program for promoting the goal or that all subjects who are indistinguishable (prior to any creation of distinctions by a selection process) should be treated the same. If Rex sets out to protect a right, however, we would normally expect both that all subjects are indistinguishable with respect to possession of the right and that all subjects who are indistinguishable should be treated the same. All subjects will be indistinguishable if the right in question is universal; and all subjects who are indistinguishable should be treated the same because the reason for political decision provided by the existence of a right is index-free. ${ }^{60}$ The example of Rex's economic-stimulation program shows that it is possible to have a reason which is universal but not index-free. The example of a hypothetical right to speak belonging only to persons over six feet tall shows what it would be to recognize a reason that was index-free but not universal. Index-free-ness and universality are distinct and independent properties. The source of the difference between Rex's economic-stimulation program and his free-speech program is just what we said it was in the first place. It is

59. Indeed, that assumption is necessary to make Rex's random selection of beneficiaries rational in terms of the natural goal of achieving the desired stimulation at minimum cost to Rex or the fisc. Of course it might be that there are small differences in propensity to spend windfall income and that the random selection of beneficiaries was a limited departure from rationality to promote perceived fairness.

60. I continue to assume that the costs of protecting the right are not index-dependent. 
the index-free-ness of reasons based on rights. ${ }^{61}$

I have devoted some pages to arguing that Rex's free-speech program is irrational in a way his economic-stimulation program is not. Although I have considered only legislative programs, I have compared a legislative program based on policy with a legislative program based on rights. We can be certain that any difference we have discovered depends on the nature of the programs and not on the branch of government involved.

There may still be readers who think that the difference between the programs is more a matter of fairness than of rationality. Some readers, for example, may think that both programs are unfair and that the reason the free-speech program seems more objectionable is because fairness is specially important in the distribution of fundamental rights such as the right to speak. I shall not repeat the arguments I have already made about why I think the difference is more than this. I would make two new points: First, if fairness is specially important in the distribution of fundamental rights, then that alone is a partial justification for Dworkin's claim that consis-

61. Essentially the same point about the difference between Rex's programs can be made in another way which some readers may find helpful. As I observed earlier, Dworkin and his critics apparently agree that it is in some sense a truism that like cases should be treated alike. Consistently with this, we can suggest that the difference between the economic-stimulation program and the free-speech program is in what makes cases like or unlike.

In the economic-stimulation program, the effect on the economy of subsidizing any particular subject depends on the number of other subjects being subsidized. Two subjects are therefore "like" for purposes of this program only if, from the point of view of each of the two, the same number of "other" subjects have been chosen to receive subsidies. In the free-speech program, on the other hand, the effect on the underlying goal of protecting any particular subject does not depend on who else is being protected. All subjects are therefore "like" for purposes of this program regardless of how many are protected.

The reader may have noticed that, as I have defined "likeness" in the economic-stimulation context, it is tautologically true in that context that like cases are treated alike. If we consider any pair of subjects and any possible scheme for distributing subsidies, the two subjects in question will be "like" in the number of "others" (from the point of view of each) who receive subsidies under that scheme if and only if they are themselves treated the same by that scheme-if and only if they both receive a subsidy or both receive none. The requirement that like cases be treated alike therefore imposes no effective constraint on the design of the economic-stimulation program. (It would do so, of course, if we introduced some further factors relevant to "likeness," such as a varying propensity to spend. We shall not pursue that possibility.) With regard to the free-speech program, however, the requirement that like cases be treated alike does impose an effective constraint. Because all subjects are "like" regardless of who is protected, the requirement of treating like cases alike limits the possible designs of the program to two, that in which no one is protected and that in which everyone is.

It may seem odd that the requirement of treating like cases alike has no force at all in the first context and considerable force in the second, but that is the truth of the matter. The artificial simplicity of our examples contributes to the starkness of the contrast, but we see that the requirement that like cases be treated alike has much greater impact on a program to protect rights than on a program to promote a general social goal.

The reader will find a fuller treatment of a problem which is structurally analogous to the problem of what it means to treat like cases alike in Chapter 6, Utilitarian Generalization, of my Utilitarianism and Cooperation (Oxford University Press, forthcoming). 
tency is more important in decisions of principle than in decisions of policy. Second, it is only a partial justification. "Fundamental rights" are presumably limited to trump-rights, and if fairness is specially important only in connection with trump-rights, Dworkin is left with no explanation of the strong requirement of articulate consistency which applies to courts in private litigation not involving rights as trumps. I shall explain presently how my own suggestion about the difference between Rex's programs allows us to account for the importance of consistency in cases involving rights which are not trump-rights.

Other readers may feel that the main objection to Rex's freespeech program is one which falls right on the borderline between a claim of unfairness and a claim of irrationality. It is that Rex makes distinctions in the conferring of benefits without offering any reason at all. I agree that this is a strong objection to the program. I disagree only in thinking that it does not reflect the full measure of the program's faults. The free-speech program is not only worse than the economic-stimulation program we have described. It is worse than a program in which Rex gives pure gifts of a thousand dollars, unmotivated by any consideration save generosity, to one-thousand randomly chosen subjects and nothing to the rest. The problem is therefore not simply that Rex makes a distinction without having any reason for it. The problem is that in not protecting some of his subjects in their desire to speak, he ignores a positive reason for protecting them which his use of the idea of rights commits him to. ${ }^{62}$

I have been suggesting that what is special about rights is that they constitute index-free reasons for political decisions. The example of a right I have relied on so far, the right to speak, is one which most people would regard as a trump-right. But the idea that rights are index-free reasons applies also to rights as individuated claims. Any argument for a political decision which begins from the consequences for an individual, as opposed to beginning from the desira-

62. I must admit that Dworkin tends to refer to the strong requirement of consistency in dealing with rights as a matter of fairness, even though I have suggested that it is primarily a matter of rationality. Perhaps I have not been explicating Dworkin's point at all. But there are other possible explanations for his greater emphasis on fairness. One possible explanation is that he has conflated the point I have been expounding with the separate point that fairness is specially important in the distribution of fundamental rights. Given Dworkin's unclarity about the relevance of trump-rights to private litigation, this seems quite likely. Another possibility is that 'Dworkin does not recognize any distinction between constraints of fairness and constraints of rationality as these apply to governmental behavior. The "constructivist" view of political morality which is manifested in "Justice and Rights" seems to suggest that for Dworkin the only reason to care about rationality in governmental behavior is because fairness requires it. RighTS (h), supra note 5, at 159-68. 
bility of promoting some general social goal, posits a reason which is index-free.

Consider one of Dworkin's favorite cases, MacPherson $v$. Buick. ${ }^{63}$ Regardless of whether Mr. MacPherson has a trump-right not to suffer on account of the negligence of Buick, if the argument for compensating MacPherson for his injuries begins from the desirability of making him whole, then there must be an analogous argument for making whole any other plaintiff who has suffered a similar injury. To be sure, there may be differences in the cases which eventually lead us to deny recovery to the other plaintiff. Real decisions about how far to extend rights, and about how to mesh the protection of rights and the pursuit of policies, are vastly more complex than my Rex examples suggest. But the basic point remains. If it is a good to compensate MacPherson, it is prima facie a similar good to compensate other plaintiffs who have suffered similar harms.

Actually, I have just muddled together the universality and the index-free-ness of rights. There are two aspects, which ought to be distinguished, to the justification of the claim that if it is a good to compensate MacPherson, it is prima facie a similar good to compensate other plaintiffs who have suffered similar harms. One aspect is the assumption that if harm to MacPherson counts as a bad, then a similar harm to someone else counts as a bad also; or in other words that MacPherson is not distinguishable from other persons with regard to the importance attached by our political theory to his and their interests. In effect, this is the assumption that the right to be protected from physical injury occasioned by another's negligence, even if it is not a trump-right, is universal. The other aspect of the justification of the claim above is the assumption that a later plaintiff who has the same sort of interest as MacPherson, while he may benefit from the analogy to MacPherson, cannot be prejudiced by the fact that MacPherson has already sued and won. We assume that the force of the reason for allowing plaintiffs like MacPherson to recover has not been exhausted by his recovering. We assume, in other words, that the reason underlying MacPherson's recovery is index-free. That, indeed, is why we unhesitatingly call it a "right".

Observe that the reason underlying MacPherson's recovery might, logically, have been a reason that was not index-free. It would not have been illogical for the court which decided in favor of MacPherson to have done so on the ground that too large a fraction of the nation's wealth was owned by corporations, and that a transfer

63. MacPherson v. Buick Motor Co., 217 N.Y. 382, 111 N.E. 1050 (1916). 
from Buick to MacPherson would be good social policy. This reason would be index-dependent. It would not follow from MacPherson's winning on this ground that there is any reason at all for a later plaintiff to win. MacPherson's recovery might have exhausted the force of the reason on which it was based. The transfer to MacPherson might have been just the transfer away from corporations that was needed. If so, later plaintiffs, even if they are totally indistinguishable from MacPherson in every respect except that they sue after him, should lose. ${ }^{64}$

It may seem odd to suggest that the court might logically have decided for MacPherson on the basis of a reason which would provide no support at all to a later plaintiff who was indistinguishable from MacPherson except in being later. Indeed, I hope it does seem odd. That oddity, I believe, is precisely Dworkin's point.

When we look at how courts behave, we see that they generally attempt to discover and to extrapolate the reasons for prior decisions. They do not ordinarily ask themselves whether the force of any particular reason has been exhausted by the decisions that reason has already been used to justify. But if the reason in question was indexdependent, that inquiry would be indispensable. A court wondering whether to follow or extend the rule of MacPherson does not ask whether whatever the decision in MacPherson was meant to accomplish was fully accomplished so far as it was desirable by that decision itself. But if the court thought the decision in MacPherson might have been based on the desirability of reducing the wealth of corporations, it would have to consider that question.

In sum, the standard judicial approach to common-law precedent indicates that courts view common-law decisions as based on arguments that begin from the interests of individuals. ${ }^{65}$ Such arguments

64. It may seem implausible to suppose that the transfer to MacPherson was, all by itself, just the transfer that was needed, but the basic point remains. After some number of plaintiffs have recovered, corporate wealth will have been decreased enough. After some number of cases follow MacPherson's case, the reason on which they were all based will vanish utterly, even though similar plaintiffs continue to appear. As I explain in the text that follows, courts do not talk as if the reasons they rely on behave this way.

65. Lest $I$ be misunderstood, let me make it clear that distinguishing between arguments which begin from the consequences for an individual and arguments which do not is perfectly consistent with the belief that all political goals are ultimately validated by their contributions to individuals' welfare. Even if we do not regard economic stimulation or the containment of corporate power as intrinsic goods, even if we regard them as desirable only to the extent that they ultimately make individuals better off, still, in positing such a goal as economic stimulation we do not focus directly on the ultimate distribution of the benefits we expect to flow from it. Under some program designs, the individuals we propose to affect directly will not even be the individuals who will reap the final benefits. Because the direct effects of the program do not represent the final goal, there is no reason to assume that everyone should be directly affected in the same way. If we were in a position to control precisely the final effects of the 
posit reasons for political decisions which are index-free. This is why precedents have "gravitational force". This is an important sense in which common-law adjudication is about rights. ${ }^{66}$

I shall close this section with three further observations. First, I do not think either the principle/policy distinction or the distinction between index-free and index-dependent reasons is "the key" to understanding common-law adjudication. The patterns of judicial reasoning are much more complicated than any attempt that has yet been made to describe them. I do think, however, that the distinction between index-free and index-dependent reasons is a significant one, which helps to make sense of what courts do and of what Dworkin says about them.

Second, it may be that the most important line suggested by this section is not really between rights and policies, but between rights and a certain kind of policy on the one hand and a different kind of policy on the other. The crucial point, it seems to me, is the point I have attributed to Dworkin about how courts view the reasons relied on in prior cases. Courts assume (in general) that whatever was a good reason in an earlier case is still a good reason if it is relevant to the present case. Now, even though the policies of economic stimulation or decreasing corporate wealth do not generate reasons which behave this way, there may be other policies which do. For example, the policy of economic efficiency may generate reasons which behave this way. It seems plausible to suggest that whatever we would do in one case on the ground that it promoted efficiency, we would also want to do in later similar cases. The goal of efficiency is not inherently limited in the way the goal of economic stimulation is.

I shall not attempt to describe more carefully this suggested difference between efficiency and economic stimulation. One reason is that the concept of efficiency is widely invoked and widely misun-

program, then perhaps the presumption would be that we would want to affect everyone the same way at that level, but ordinarily the details of the final effects are largely uncontrollable. On the other hand, when (or to the extent that) we are protecting rights, even rights as individuated claims which are not trump-rights, the direct effect is the final goal. The presumption therefore is that everyone similarly situated should be directly affected in the same way.

66. I have claimed that courts talk as if they do consider only (or primarily) arguments about rights. I have not, as it turns out, said much about whether they should consider only arguments about rights. Anyone who has read this far can plug in some standard arguments about why questions like how far to press a program of economic stimulation are less apt for judicial decision than questions about rights. In my terminology, the idea is that courts are good at elaborating and weighing index-free reasons, but weak at figuring out just how indexdependent reasons depend on the relevant index. I shall not consider further in this section the question of what courts should do, first, because I have nothing now to add to the standard arguments and, second, because Dworkin's arguments seem more relevant to the descriptive than to the prescriptive claim. 
derstood, and this is not the proper occasion for plunging into that morass. Another reason is that if we looked more closely we would quickly discover other types of policy intermediate in their characteristics between efficiency and economic stimulation. If I may nonetheless give names to the two sorts of policy I have indicated, I would call economic stimulation a "satiable" policy (since it is a good thing which it is possible to have too much of) and efficiency a "non-satiable" policy (since it really is not possible to have too much of efficiency, properly defined, though it may be possible to have too much of certain supposed expedients for achieving it). Ignoring the fact that the family of possible policies does not divide up quite so neatly as this language suggests, I think it is worth considering whether the most important demarcation in the class of political aims, at least for purposes of understanding what courts do, might not be between rights and non-satiable policies on the one hand, and satiable policies on the other.

Third, the distinction between satiable and non-satiable policies may be the key to solving another puzzle about Dworkin's theory. Dworkin does not doubt that when a court decides a case under a statute, it must consider whatever policy the statute embodies. It may seem that because of Dworkin's holistic approach to legal questions-his assumption that the law is a seamless web, every part of which is connected to every other part-any policy that is part of the justification for any statute becomes relevant to the decision of all legal questions, including common-law questions. If this were so, then the distinction between principle and policy would be of little practical importance, since almost any policy a court might wish to rely on in deciding any case would be part of the justification for some feature of some statute. Plainly Dworkin does not intend this wholesale invasion of the common law by statutory policies. An explanation of why all policies embodied in statutes do not automatically become relevant to common-law questions is provided by the distinction between satiable and non-satiable policies. If the legislature has passed a statute based on a satiable policy, there is no reason to assume that they have not pushed the policy as far as they think it should be pushed. Therefore legislative action based on a satiable policy does not ordinarily invite further judicial action (outside the range of cases in which the statute is directly implicated) in pursuit of the same policy.

\section{B. Principles, Policies, and Right Answers}

There is a possible argument for the proposition that judges 
should consider only arguments of principle, which runs as follows: Questions of principle have right answers; questions of policy do not. Judges deal only with questions that have right answers. Therefore, judges must deal only with questions of principle.

Dworkin does not make this argument in so many words. $\mathrm{He}$ might disown it in the form I have just given it. On the other hand, the argument as stated is suggested by Dworkin's "democratic-theory" argument for the proposition that judges should rely on principle. The version of the democratic-theory argument that appears in "Hard Cases" may seem quite different from the argument I have given, but the democratic-theory argument of "Hard Cases" is untenable as it stands, since it apparently depends on the assumption that judges enforce only trump-rights. ${ }^{67}$ That assumption, as we have seen, is mistaken. In "Seven Critics" the democratic-theory argument is restated in such a way as to eliminate explicit reference to trump-rights and to bring the argument closer to the argument I have given. ${ }^{68}$ Whether the argument I have given is Dworkin's or not, it is an argument which would occur to any reader of Dworkin, and it is worth brief consideration.

For many readers, the most problematic part of the argument will be the second premise ("Judges deal only with questions that have right answers"). Despite the controversy about whether questions properly presented to judges always or almost always have right answers, I shall not dispute the second premise in this essay. For the moment I am interested in the first premise, in whether it is plausible to suppose that questions of principle and questions of policy differ in the extent to which they have right answers. ${ }^{69}$

Dworkin is ambivalent about whether questions of policy have right answers. Sometimes he suggests that legislation by a representative body should be viewed as a form of "procedural justice", by which he means what Rawls calls "pure procedural justice". That is, he suggests that there is no non-institutional criterion for right decisions about the general welfare; all we can say is that decisions on policy are right, or just, or acceptable, if they are produced by a democratically constituted representative body. ${ }^{70}$ Sometimes, however, Dworkin seems more willing to accept that there may be cor-

67. Rights (h), supra note 5 , at 85 .

68. RIGHTS (p), supra note 2, at 322-24; Seven Critics, supra note 5, at 1235-37.

69. Even this issue I shall treat superficially. What is really needed, both for present purposes and for more general purposes in the investigation of the relation of law to morality, is a plausible explanation of what a right answer is. Dworkin does not provide this explanation, nor shall $\mathrm{I}$, at least in this essay.

70. See note 68 supra. 
rect decisions about the general welfare, at least in theory, and to defend the democratic legislative process on the ground that, under suitable restrictions, it is the best means we can devise for generating correct decisions. ${ }^{71}$

If Dworkin wished to maintain that questions of policy do not have right answers even in theory, he would have some scrambling to do. He has made it clear that questions requiring consideration and evaluation of general social consequences, questions we would ordinarily speak of as questions of policy, must be decided by courts if they are made relevant by a statute, or by community morality, or by the "point" of a social institution such as the institution of property. ${ }^{72}$ If courts must sometimes consider these questions about policy, and if all questions considered by courts have right answers, then some questions about policy must have right answers. If some such questions have right answers, it is difficult to see why all such questions do not have right answers, at least in theory. ${ }^{73}$

In sum, Dworkin seems to be committed to the idea that questions of policy do have right answers in theory. This is perfectly consistent with a claim that legislatures will decide some questions better than courts and that courts will decide others better than legislatures. But it makes it impossible to argue that judges are limited to questions of principle because those questions and only those have right answers.

It may seem that we have moved too fast and that we have ignored a difference between the way we talk about questions of principle and questions of policy. Dworkin's argument for the existence of right answers has never amounted to much more than assertions about the way we think and talk. (His recent essays focussing on the "right answer" problem consist primarily of rebuttals to various pos-

71. E.g., Rights (h), supra note 5, at 276-77.

72. See note 43 supra.

73. Admittedly, a court considering a policy question will ordinarily, or perhaps always, confront a narrower range of possible decisions on the basis of the relevant policies than the legislature confronts. But if there are policy questions that have no right answers, there is no obvious reason to expect that the narrowing of possibilities that accompanies the transfer of the question from the legislative to the judicial realm will always bring it about that just one answer among those that remain is correct. In other words, if we believe that policy questions always have right answers in the form in which courts consider them, the only plausible explanation of this fact would seem to be that policy questions always have right answers, period.

It is perhaps worth noting that the most common reason for doubting that policy questions have right answers (at least for persons who, like Dworkin, believe that government should promote the satisfaction of individual preferences) is worry about interpersonal comparison of utility. But this reason ought to affect all questions or none. Genuine scruples about interpersonal comparisons would make it impossible even to compare benefits and disadvantages to two parties, which Dworkin undeniably contemplates that courts shall sometimes do in implementing the right to the concern of others. E.g., Righrs (h), supra note 5, at 99. 
sible arguments for the claim that there are not right answers. ${ }^{74}$ ) Accepting for the moment that we frequently talk as if there are right answers to questions of principle, even in hard cases, it might be suggested that we do not talk the same way about questions of policy. If we talk as if there are right answers to questions of principle, and if we do not talk as if there are right answers to questions of policy, then perhaps there is a difference after all. If the difference is not immediately apparent, we may need to look harder.

Unfortunately for this line of argument, it is far from clear that we really talk about questions of policy differently from the way we talk about questions of principle. Even in the area of policy, we talk as if there are right answers more often than not. People who argue in favor of more military spending ordinarily talk as if there is a right answer to the question whether more military spending is desirable. So do people who argue against more military spending. People who argue in favor of strict environmental protection laws talk as if the question whether such laws are a good thing on balance has a right answer. So do people on the other side. People who argue that we should have tax deductions for three-martini lunches and people who argue that we should devote more resources to energy research or to support of the arts are all alike in talking as if these policy questions have right answers.

This is connected with a point I made in a footnote in the first section of this essay. ${ }^{75}$ The legislative process in this country may weigh and compromise competing interests. But it does not merely weigh and compromise what Dworkin calls "personal preferences", as opposed to "external preferences". An important function of public political debate is to line up support for various positions among persons who are not directly affected. The appeal to these disinterested parties is ordinarily based on claims that certain political decisions are either more just or more conducive to the general welfare than others. Even when the claims are about the general welfare, they assume that some answers to questions about how to promote the general welfare are right and others wrong. It is not easy to imagine how else one could try to enlist support for political decisions among parties not directly affected. ${ }^{76}$

74. Can Rights Be Controversial?, in RigHrs (h), supra note 5, at 279-90; Dworkin, No Right Answer?, 53 N.Y.U. L. REv. 1 (1978) (reprinted, in revised form, from LAw, MoRALITY, AND SOCIETY: EsSAyS IN HONOR OF H.L.A. HART 58 (P. Hacker \& J. Raz eds. 1977)).

75. Note 18 supra.

76. I note again that Dworkin seems to agree with me about this. See note 18 supra. It might be suggested that another way of lining up support for a position among persons not directly affected is by log-rolling ("You vote for my bill, I'll vote for yours"). Undeniably, log- 
The political process and public political debate are complex affairs, and I have oversimplified egregiously. But my point about discussions of policy is just Dworkin's point about discussions of cases at law. If we look at what we do and say, ignoring any preconceived idea that legislative questions lack right answers, we will discover that more often than not we talk as if there are right answers to these questions. So much the worse, some readers will say, for the attempt to draw inferences from the way we talk. Perhaps that reaction is the right one. But it is no comfort to anyone who would demonstrate a difference between policy and principle by pointing to differences in the way we talk about them. ${ }^{77}$

If we take it as established that questions of policy and questions of principle are not distinguishable in respect of having right answers, then the argument I stated at the beginning of this section-that judges are limited to questions of principle because those questions and only those have right answers - cannot be maintained. There is, however, a possible fall-back position for the proponent of the argument. Still drawing inspiration from the way we talk, he could point out that we do not ordinarily say a legislator has a "duty" to vote for correct legislative outcomes. That suggests the following reformulation of the argument: Our system imposes no political duty on officials to produce correct policy decisions. Our system imposes a duty on judges to decide each case correctly. Therefore judges' decisions cannot be policy decisions.

As with the original formulation of the argument, I shall concede, for purposes of this essay, the second premise ("Our system imposes a duty on judges to decide each case correctly") and focus on the first. The first premise ("Our system imposes no political duty on officials to produce correct policy decisions") is based on the observation above that we do not ordinarily talk of a legislator's "duty" to vote for correct decisions. But in passing from that observation to the first premise of the argument, the observation is transformed in

rolling goes on in legislatures. To some extent it is a good thing. But for the most part the goals legislators pursue via log-rolling are the goals favored by their constituents, and the constituents choose among goals in large part on the basis of their own external preferences.

77. It might be objected that even if public debate is based on the supposition that there is a right answer to such questions as whether we should have strict environmental protection laws, no one supposes that there is a right answer to every question of detail about how the laws should work. I think this objection is mistaken. It is true that public debate about matters such as environmental protection rarely focusses on questions of detail. But that is just because large questions must be settled first. Once they are settled, other large questions have a stronger claim on the general attention than the questions of detail which follow upon the resolution of the original large questions. When questions of detail (relatively speaking) like the question of the tax deduction for the three-martini lunch are publicly debated, they are debated as if there were a right answer. 
two ways. First, it is changed from a statement about the way we talk to a statement about what duties our system imposes. Second, it is changed from a statement about legislators to a statement about officials generally, including judges. Both changes are problematic.

As to the first change, it is true that we do not ordinarily speak of a legislator's "duty" to vote for correct decisions. But that may be only because we normally reserve the word "duty" for obligations that are relatively clear. Even if there are right answers to policy questions, it is usually far from obvious, what the right answers are. It would seem odd to many people to speak of the legislator's "duty" to vote for the correct outcome in a case where the identity of the correct outcome was highly controversial. I do not mean to claim that duties cannot be controversial. I mean only to point out that our disinclination to speak of legislators' duties may refiect nothing more than a general speech habit of not calling obligations duties when they are controversial. Now, the argument in which the premise we are analyzing appears does not respect this speech habit. The second premise of the argument asserts in effect that judges have many controversial duties. It may well be that, as the word "duty" is used in the second premise, legislators do have a duty to vote for correct policy decisions. In sum, it may well be that if the word "duty" is used consistently throughout the argument, the first premise is false even as applied to legislators. In any event, the first premise, even as applied to legislators, is not adequately supported for purposes of inclusion in this argument by the observation about the ordinary use of "duty" which inspired the argument.

The second change, it will be recalled, transformed the observation about legislators' duties into a premise about the duties of officials generally. Even if we assume arguendo that our system imposes no duty on legislators to produce correct policy decisions, the extension of this claim to cover officials generally is unjustified. We would be justified in extending the claim if the only plausible reasons for legislators' having no duty to vote for correct policy decisions applied with equal force to all officials. But as it happens, the most plausible way of explaining the absence of legislators' duties in this regard has no application to judges.

We are still assuming that there are right answers to policy questions. If this be granted, why might we deny that legislators have a duty to vote for correct outcomes? We might deny it if we thought that the best way for a legislature to go about generating correct decisions of policy was for each legislator to vote in response to his mailbag. It is not clear that we do think this. The question whether 
a legislator should vote his constituents' views or his own is an ageless one about which our political culture is schizophrenic. But, as I say, we might believe that each legislator has a duty to vote his mailbag, on the ground that that approach, generally followed, will produce the best approximation to correct answers which fallible mortals can achieve. If this is why we believe that legislators have no duty to vote for correct policy decisions, then obviously the argument does not establish that judges have no duty to make correct policy decisions. Judges do not participate in a process calculated to combine many votes not based on views of correct policy in such a way as to produce decisions which reflect correct policy nonetheless. All of this may be a reason to prefer that policy issues be decided so far as possible by legislatures rather than by courts. That I do not deny. My point is just that the reformulated argument we are discussing, depending as it does on the premise that no officials have duties to make correct policy decisions, begs the question as to judges instead of proving anything about them. It says nothing against the possibility that there are some genuine policy questions which we prefer to leave, or at least are content to leave, to judges, and as to which we think judges have a duty, albeit a controversial one, to produce correct decisions. ${ }^{78}$

It has not been my object in this section to prove that judges ought to make policy decisions. I have attempted to demonstrate only that the conclusion that judges are limited to arguments of principle cannot be based (at least without further argument) either on the premise that policy questions lack right answers or on the premise that no official has any duty to decide policy questions correctly.

\section{Principles and Policies in Practice}

There is a passage in "Seven Critics" in which Dworkin undertakes to explain why it matters in practice whether we instruct judges to consider only arguments of principle. ${ }^{79}$ If we are in doubt about just what Dworkin intends by the principle/policy distinction, we

78. It might be suggested that a judge can have no duty to decide a policy question correctly because no individual has a right to correct policy decisions. This assumes what $I$ think is surely false, that no duty can exist without a correlative right. Is it not plain that a judge can sometimes have a duty to decide a criminal case against the defendant, even if no one has a right that the case be so decided? Even denying that there can be a duty to decide against a criminal defendant would not help the proponent of the argument currently under consideration in the text. The second premise of that argument is that our system imposes a duty on judges to decide each case correctly. If there can be no duty to decide a case against a criminal defendant, and if there is always a duty to decide correctly, then a decision against a criminal defendant can never be correct. This cannot be.

79. RugHTs (p), supra note 2, at 311-17; Seven Critics, supra note 5, at 1223-29. 
might hope to learn something about what the distinction is from a discussion of why it matters. As it turns out, only a part of Dworkin's discussion sheds light on the principle/policy distinction. However, the part which is unhelpful on this point is interesting in itself.

Dworkin begins by describing five possible theories of rights which a judge might hold (other than a "strict deontological theory"). The first three theories are different utilitarian theories of rights. The fourth theory is a theory based on an abstract "right to the concern of others".80 The fifth theory is a theory of "institutional rights" based on "reasons of fairness [which] require that settled institutions be administered in accordance with their rules and with the expectations these rules generate . . . ."81 Dworkin apparently believes that a judge who accepts any of these five theories will decide cases differently if he is instructed to consider only arguments of principle (that is, arguments about rights) than he will if he is allowed to consider arguments of policy. ${ }^{82}$ But what Dworkin devotes most attention to is the claim that a judge who holds either of the last two (non-utilitarian) theories will decide cases differently if he considers only arguments of principle. It is Dworkin's argument in support of this claim that we shall consider.

Dworkin hypothesizes a judge who is required to develop a scheme of riparian water rights without significant help or interference from the legislature, and he suggests a variety of things the judge might do if he were guided solely by policy. The judge might, for example, take as one of his aims the reduction of food prices relative to the prices of manufactured goods. Alternatively, the judge might divide the state into two distinct areas, with one set of rules to govern riparian water use in one area, and a different set of rules in the other. Or he might announce rules which are to be effective for a certain number of years but which are to be replaced by different rules when the effects desired from the first set have been achieved. All of these things Dworkin says the judge might do if he were free to decide on the basis of policy; none of them, according to Dworkin, would be appropriate if the judge must decide on principle and if he holds one of Dworkin's non-utilitarian theories of rights. ${ }^{83}$

I should like to set aside for the time being Dworkin's suggestion

80. RIGHTS (p), supra note 2, at 314; Seven Critics, supra note 5, at 1226.

81. RighTS (p), supra note 2, at 314-15; Seven Critics, supra note 5, at 1226.

82. Rights (p), supra note 2, at 317; Seven Critics, supra note 5, at 1228-29.

83. Dworkin actually makes this argument only about the fourth theory. But he prefaces it and follows it with claims about both the fourth and fifth theories. He plainly assumes that the "institutions" presupposed by the fifth theory would not allow the judicial decisions he puts beyond the pale. Since Dworkin obviously believes in general that the institutions of the com- 
that a judge deciding cases on principle could not take as one of his aims the reduction of food prices. This is the part of Dworkin's argument which I think does tell us something about the principle/ policy distinction. For that reason, I shall postpone consideration of it until we have dealt with Dworkin's other claims.

Dworkin says that a judge deciding cases on principle could not introduce different rules for different parts of the state or announce rules which were to be effective for only a predetermined time. I think he is right that we would regard a judge's attempt to do either of these things as decidedly odd. ${ }^{84}$ But I doubt whether this tells us anything at all about what arguments judges are entitled to consider.

We must distinguish between what I shall call "input restrictions" and what I shall call "output restrictions." An input restriction is a restriction on the kinds of argument a judge may consider. Thus, the requirement that a judge consider only arguments of principle (assuming we know what those are, and assuming that some arguments are not arguments of principle) is an input restriction. An output restriction is a restriction on the kinds of results a judge can announce. Thus, if we believe that judges must announce only rules possessing some minimum degree of generality, or if we believe that judges must announce only rules which are to apply throughout their territorial jurisdiction, those would be output restrictions.

Now, an important point is this: Any output restriction is logically consistent with the total absence of input restrictions. We might, as a logical matter, say that judges are free to consider whatever arguments they regard as relevant to the problem before them, provided only that when they announce results, or rules, or whatever, they must observe certain output restrictions such as those we have already mentioned (and perhaps others). Indeed, it is possible that the actual constraints on common-law decision-making are better described in terms of output restrictions than in terms of input restrictions. Some critics of Dworkin have suggested just that. ${ }^{85}$

mon law are based on a theory which gives a central place to the "right to the concern of others," his tendency to conflate his fourth and fifth theories is understandable.

84. Courts have occasionally been known to announce that they would continue to enforce an existing common-law rule only until some specified date and that if the legislature did not revise the rule by then, they (the courts) would revise it themselves. This behavior, while it may be justified in some cases, is pathological in terms of our standard views about the judicial role. Furthermore, it is probably best understood not as an announcement that the court is going to recognize a new common-law rule in the future, but as saying that the old rule is already undeserving of enforcement and will be continued in effect for some brief time only out of respect for reasonable expectations. That is a quite different matter from the differentrules-for-different-times example Dworkin has in mind.

85. See Greenawalt, supra note 23, at 1010 (citing Note, supra note 23, at 1194).

All of the output restrictions so far mentioned have been cast as restrictions on the rules 
With the distinction between input and output restrictions in mind, let us consider Dworkin's claim that a judge making decisions on principle could not announce different rules for different parts of his jurisdiction, or different rules for different (future) times. The purported object of the passage in which this claim occurs is to explain why the input restriction to arguments of principle makes a practical difference. Yet it seems that all Dworkin does is to remind us of the existence of two output restrictions which are generally recognized as binding courts. An unsympathetic reader might plausibly complain that Dworkin says nothing at all to the point.

A more sympathetic reader might say that Dworkin at least suggests an argument--he suggests that if the input restriction to arguments of principle is observed, then the aforementioned output restrictions must be satisfied. Thus the input restriction does make a difference. There are two problems with this defense of Dworkin. First, Dworkin does not argue that if the input restriction is observed, the output restrictions we have identified must be satisfied. He simply asserts that a judge who was concerned only with fairness between the parties would not produce different rules for different parts of the state, or different rules for different (future) times. This may be true, but it is not so obvious that it can be granted without argument. 86 Second, even if it is conceded arguendo that an input restriction to arguments of principle would guarantee outputs consistent with the output restrictions we have identified, this may not mean that the input restriction "makes a difference". What we have conceded arguendo implies that in the absence of any output restrictions the input restriction would make a difference. But if we are committed to the output restrictions regardless of whether we accept any input restrictions, then an input restriction is not shown to make a difference in practice by being shown to restrict possible outputs in the same way as certain independently recognized output restrictions.

Dworkin might still argue that the input restriction makes a dif-

courts can announce. Dworkin might object that in talking about output restrictions, I misapprehend the nature of judicial "output." He might say I assume courts are primarily engaged in announcing rules, whereas in fact they are primarily engaged in deciding cases and giving reasons. This objection is misguided. I do not assume that courts are primarily engaged in announcing rules. I assume only that to the extent that courts announce rules, we expect them to announce rules for their entire jurisdiction, and for the foreseeable future, and so on. I do not suggest that courts must decide cases by announcing rules of a certain sort, but only that if they decide a case by announcing a rule, then the rule must be of a certain sort.

86. If the assertion at issue in the text is true, I suspect it is true for reasons like those discussed further on in connection with the inappropriateness of judicial pursuit of lower food prices. Compare note 88 infra. 
ference because we do not accord the output restrictions independent validity. He might suggest that the only plausible way of accounting for the output restrictions is by viewing them as a check on whether the input restriction is complied with. Thus, if we assume that there is an input restriction to arguments of principle, and if we assume that from such arguments only results consistent with the specified output restrictions can follow, then we can explain the output restrictions as a handy means for catching violations (or, in the course of the judges' own reasoning, incipient violations) of the input restrictions. Of course, the output restrictions would not catch all violations. Inadmissible arguments might be used to justify admissible outputs. But they would have some value, since inadmissible outputs would certainly indicate that inadmissible arguments had been considered. A problem with this suggestion is that, even if the output restrictions so far identified can be regarded in this light, there are other output restrictions we recognize which cannot, because they impose restrictions on possible results over and above those entailed by the supposed input restriction to arguments of principle. The existence of some output restrictions which cannot be accounted for by reference to this input restriction raises serious doubts about whether any output restrictions are best accounted for in the manner suggested.

An example involving an output restriction which cannot be explained by an input restriction to arguments of principle has already been described in a footnote to an earlier section. ${ }^{87}$ We observed that a legislature could adopt the rule of MacPherson v. Buick for automobiles and at the same time explicitly forbid applying the rule to washing machines. We observed also that the distinction could well be justified solely on grounds of principle. The legislature, taking into account the reluctance of automobile manufacturers to settle morally meritorious claims, the willingness of washing-machine manufacturers to settle such claims, and the litigiousness of washingmachine purchasers, might arrive at the specified result even though it had no purpose except to protect the rights of all parties concerned. But, as we have previously noted, this result, which is acceptable when announced by the legislature, would not be acceptable if announced by a court on the same grounds. There is apparently an output restriction on the courts whose existence cannot be accounted for by an input restriction to arguments of principle.

87. Note 54 supra. 
If we are not to oversimplify, we must look more closely at this supposed output restriction. Observe that there is no general output restriction which would prevent courts from developing one rule for automobiles and a different one for washing machines in an appropriate context. The area of products liability might even be the appropriate context. It is not inconceivable that the courts should have developed the "inherently dangerous" rationale relied on in MacPherson and should ultimately have decided that while automobiles are inherently dangerous, washing machines are not. Even if such a result would have been mistaken, it would not have been objectionable in the way different rules about water use for different parts of the state would be objectionable if announced by a court. It might be suggested that if courts can draw a line between automobiles and washing machines on some grounds (for example, the ground of inherent dangerousness) but not on others (relating to the behavior of various classes of persons in the management of disputes), then it is really an input restriction we are dealing with after all. It must be that in formulating rules courts are forbidden to consider the proclivities of classes of persons with regard to dispute management. But this is surely false. Many common-law rules are shaped in part by judicial consideration of the likelihood of satisfactory extra-judicial dispute adjustment or of the danger of spiteful litigation. For example, reasons of this sort presumably underlie the common-law refusal to enforce most promises made without consideration. If the restriction manifested in our automobile/washingmachine example is not a pure output restriction, it is not a pure input restriction either. It is a hybrid. Certain sorts of argument, not inadmissible in themselves, may not give rise to certain sorts of distinction, also not inadmissible in themselves. This suggests that the original distinction between input and output restrictions was too simple, but not that it is useless. It is a first step to understanding, even though it is not fully adequate to deal with the complexity of the restrictions courts labor under. ${ }^{88}$

88. The real truth about our example may be that courts are not allowed to consider, or to produce results which suggest that they have considered, certain information, in this case information about the comparative dispute-management behavior of automobile manufacturers and washing-machine manufacturers, or automobile purchasers and washing-machine purchasers. This is information which a court is not well-suited to collect and which we are not prepared to assume courts just naturally "understand", as we might assume they "understand" how automobiles and washing machines compare in terms of inherent dangerousness. The possibility that courts are constrained not just by what arguments they may consider but also by what information they may rely on is one Dworkin devotes too little attention to. The idea that courts may rely on facts developed in the case at hand or else accessible to the common understanding fits in neatly with the suggestion further on in this section about why (or when) courts should not worry about food prices. 
Further discussion of this complicated and, I think, important topic would take us far beyond our text. By bringing in output restrictions, Dworkin raises interesting issues, but it is doubtful that he advances or clarifies his position concerning what arguments courts may consider.

We turn now to Dworkin's suggestion about judicial attention to food prices. As we have noted previously, Dworkin says that a judge holding a theory of rights based on the right to the concern of others would regard as "irrelevant" the aim of lowering food prices relative to prices of manufactured goods. ${ }^{89}$ Here, just as in his reference to output restrictions, Dworkin appeals to an intuition which I assume is widespread. We would think it odd for a judge to announce a rule of water law and explain that the rule was justified because it would tend to encourage agriculture at the expense of manufacturing. Unfortunately, Dworkin says nothing about why this judicial behavior would strike us as odd. Other social consequences not obviously different in kind from a lowering of food prices, such as a local economy's loss of jobs, are treated by Dworkin as relevant to what is required by concern for others. ${ }^{90}$ Perhaps our intuition that judges should not worry about food prices is mistaken and should be abandoned.

I think our intuition about the irrelevance of food prices can be defended. The first step is to recognize what sort of intuition it is. It is not an intuition that lowering food prices could never be a goal in common-law adjudication. It is only an intuition that lowering food prices is not an appropriate goal of common-law adjudication in our society. Suppose, by way of contrast, a society in which food is scarce, in which food production is difficult, and in which guaranteeing an adequate diet for the population demands that practically all of the community's resources be devoted to agriculture. In such a society any use of land which impeded or displaced agricultural production would, at least prima facie, display a lack of concern for others. In such a society, a judge who regarded himself as charged with implementing a right to the concern of others would be fully justified in formulating water law designed to encourage agriculture and lower food prices.

We see that whether it is appropriate for a judge to consider food prices depends on the general state of society. That is a proposition I assume Dworkin would have no difficulty with. But Dworkin's crit-

89. Rights (p), supra note 2, at 316-17; Seven Critics, supra note 5, at 1228.

90. E.g., Rights (p), supra note 2, at 296; Seven Critics, supra note 5, at 1206. 
ics may still be dissatisfied. They may feel that while it is all very well to say food prices are relevant sometimes and not others, still it is not very helpful and not very enlightening so far as the principle/policy distinction is concerned unless we can be a little more specific. Fortunately, we can be just that-a little more specific.

Dworkin is suggesting, none too clearly, that judges ought to decide common-law cases by standards which focus on the relations between individuals and which are available to the understanding of the individuals themselves. ${ }^{91}$ Whatever standards we think the parties should appeal to in deciding how they ought to behave or in criticizing each other's behavior, those are the standards we expect the court to apply in deciding cases. What these standards are will vary from society to society. In our society it is perfectly appropriate for the legislature to promote agriculture or manufacturing or to adjust the balance between these sectors in the pursuit of general economic welfare. But there is no such present imbalance between the satisfaction of needs for food and the satisfaction of needs or wants for manufactured products that any individual should regard himself as morally constrained to worry about the consequences of his own behavior for the balance between agriculture and manufacturing in general. ${ }^{92}$ That, I take it, is why food price policy is not relevant in our society to the implementation of the "right to the concern of others".

Right or wrong, the idea that courts should appeal in commonlaw adjudication only to standards which we would expect the individuals involved to appeal to is an important and interesting idea which Dworkin suggests without making it explicit and which others have not commented on. ${ }^{93}$

91. Compare Rights (p), supra note 2, at 317; Seven Critics, supra note 5, at 1229.

92. On a strict act-utilitarian theory, of course, the individual must regard the consequences of his behavior for the balance between agriculture and manufacturing as theoretically relevant to what he ought to do. But probably few of my readers are thorough-going actutilitarians. The text is written with "standard" intuitions in mind. Even for the act-utilitarian, if there is no noticeable imbalance between agriculture and manufacturing, and if markets for labor and other resources are functioning tolerably well, it is very likely that a rule-ofthumb which directs one not to worry about the effect of one's private choices on the balance between these major sectors of the economy is a good rule-of-thumb. Thus, one need not worry about this balance in practice.

93. It is interesting to speculate about the extent to which this Part, suggesting that courts can consider any policy we would expect individuals to consider in making their own decisions, and Part II.A, suggesting that perhaps courts can consider non-satiable policies, pick out the same policies for judicial consideration. If we regard as non-satiable any policy which is non-satiable over the range of circumstances which members of a society at a given time are likely to confront, I suspect the suggestions of these two sections reinforce one another to a considerable degree. 


\section{CONCLUSION}

I began by promising a disjointed essay, and that promise I have surely fulfilled. I do not propose to summarize all my conclusions. I do want to point out a common thread which ties together the principal conclusions regarding the nature of common-law adjudication. Let me begin by reminding the reader of the conclusions I refer to.

First, we saw that although private litigation does not always involve trump-rights, it does always involve rights as individuated claims. In common-law cases, where the individuated claim cannot be based on a statute, the source of the individuated claim is always a particularized harm. Second, we saw that there is some sense to the idea that the requirement of consistency in decision-making is specially strong in decisions based on principle, which is to say, on rights. The reason is that arguments beginning from the desirability or undesirability of some consequence for some individual have a sort of guaranteed relevance to later similar cases which (most) arguments beginning from the desirability or undesirability of general social consequences lack. Third, we found in Dworkin's comment about food prices the notion that judges ought to decide non-statutory cases by standards which are accessible to the understanding of the individuals concerned. Judges should appeal to the same standards we would expect the individuals themselves to appeal to in deciding how they ought to behave or in criticizing each other's behavior.

The common thread is the centrality of the individual. The occasions for common-law adjudication are those where there is special harm to individuals; the preferred reasons for common-law decisions are reasons founded directly on consequences to individuals; 94 and the standards applied by common-law judges ought to be standards which the parties might have apprehended and applied to themselves.

As I noted in the opening paragraphs of this essay, a central theme in Dworkin's theory of adjudication is a rather old-fashioned idea of the common law as a system of fundamental moral principles, accessible to all, and regulating intercourse between individuals, with only occasional and incidental reference to general social consequences. The methods for the elaboration of these principles are analysis of precedent and consideration of hypothetical cases,

94. I ignore here, and in the remainder of this Conclusion, the possibility that reasons based on non-satiable policies may be appropriate for judicial consideration. I am here summarizing what we have learned about Dworkin. The suggestion about non-satiable policies was a frolic of my own. 
methods peculiarly appropriate for dealing with "individual-centered" reasons for political decisions. The primary agents for the elaboration of these principles are judges, who we think are better suited than legislatures to engage in the careful parsing of relatively bounded dispute situations, repetitive in their general outlines but infinitely variable in detail, which these methods require.

I have referred to this individual-centered picture of the common law, which motivates many of Dworkin's arguments, as old-fashioned. That is not to say that it is dead or that it has lost its appeal to all but Dworkin. The idea of the common law as a set of fundamental propositions about how individuals should comport themselves towards one another, even if it is a little embarrassing to many in this post-realist era of economic and policy analysis of law, has never been expunged from the thinking of lawyers, or of judges, or even of most law professors. Dworkin's unusually forthright allegiance to this idea is an important source of the appeal of his theory, as well as of the air of unreality which (for some) surrounds it.

Unfortunately, this idea of the common law may be becoming less and less suitable to the society in which we live. It assumes that we can approach the settlement of legal disputes by asking what concern a person owes his neighbor. But whose neighbor is the manufacturer of a freon-powered aerosol deodorant, or the dumper of toxic wastes into the ocean? And what concern does an automobile manufacturer owe its purchasers in the design of its cars for crashworthiness or in the design of its purchase contracts with regard to warranties of the same? In our society it is true of more and more disputes that neither the circumstances from which they arise nor the effects of their resolution are likely to be localized in space and time. Maxims like sic utere tuo are less and less helpful in deciding cases.

If the range of cases to which traditional common-law methods are appropriate is shrinking, it is unclear what judges should do. One possibility is that they should recognize explicitly the changed nature of the problems with which they are being asked to deal and should plunge ahead as legislators pro tempore. This seems to be what Greenawalt would recommend. 95 The other possibility is that they should do their best to treat new problems by the old judicial methods and should count on the legislature to intervene when the results thus produced are unacceptable. This seems to be what Dworkin has in mind. I shall not argue here for either choice in this

95. Greenawalt, supra note 23, at 1051-52 (judge as "agent for change"). 
dilemma. - But I think the dilemma is a real one, despite the fact that, were it not for Dworkin, we might almost succeed in ignoring it.

One final point. I have referred to Dworkin's conception of the common law as being based on fundamental moral principles, accessible to all. The reader may think that by introducing "fundamental moral principles" into the discourse without making clear just what I mean, I fudge deep and important questions. The reader is absolutely right. But the questions I fudge are questions on which Dworkin seems thoroughly ambivalent, and I propose to leave them, at least in this essay, just where he leaves them. If Dworkin is ambivalent, that is as much a sign of virtue as a defect. He is ambivalent largely because he is less inclined than his contemporaries to flinch and look away from the most difficult questions about the relation of law to morality, questions no one has yet produced satisfactory answers to. ${ }^{96}$

96. What I perceive as ambivalence may be revealed as single-minded adherence to a new and important meta-ethical theory if Dworkin ever produces a satisfactory elucidation of what he calls "a special kind of intellectual activity, ... . defending a particular conception of a concept." Rights (p), supra note 2, at 351. Dworkin admits that he has not yet given "an adequate or even clear account of that activity." Id. 